\title{
REPERTORIO BIBLIOGRÁFICO SOBRE COMISIONES PARLAMENTARIAS Y DIPUTACIÓN PERMANENTE
}

ÁNGEL LUIS ALONSO DE ANTONIO

Profesor de Derecho Constitucional

Universidad Complutense de Madrid 
A. COMISIONES PARLAMENTARIAS.-1. DeRECho COMPARAdo. a) Estudios generales $y$ de Derecho comparado. b) Estados Unidos. c) Gran Bretaña. d) Francia. e) Alemania. f) Italia. g) Unión Soviética. h) Otros países: Argelia. Argentina. Australia. Bahamas. Bélgica. Brasil. Canadá. Chile. China. Cuba. Dinamarca. India. Irlanda. Israel. Japón. Líbano. Noruega. Portugal. Suiza. Uruguay. Yugoslavia. Zambia. 2. EsPAÑA. B. DIPUTACIÓN PERMANENTE.-Antecedentes medievales. Régimen constitucional histórico. Sistema parlamentario actual. 
Revista de Derecho Político, núm. 33, 1991, pp. 303-362

\title{
REPERTORIO BIBLIOGRÁFICO SOBRE COMISIONES PARLAMENTARIAS Y DIPUTACIÓN PERMANENTE
}

\author{
POR \\ ÁNGEL LUIS ALONSO DE ANTONIO \\ Profesor de Derecho Constitucional \\ Universidad Complutense de Madrid
}

La primera interpretación que puede sugerir el contenido propuesto para estas líneas sería la de considerar la relación comisiones parlamentarias-Diputación permanente como la del todo a la parte, esto es, considerar a la Diputación permanente como una comisión más. No es este el lugar más adecuado para tratar con la debida amplitud la naturaleza juridica de la Diputación permanente ni su encuadre constitucional. Tan sólo cabe ahora explicar el objeto exacto de esta indicación bibliográfica en la que se pretende recoger, no exhaustivamente pero sí de la forma más amplia posible, la relación de estudios que han tratado de un modo científico las comisiones parlamentarias y la Diputación permanente como órganos internos del funcionamiento parlamentario sin que puedan confundirse, ni aun asimilarse, en su naturaleza ${ }^{1}$ por cuanto su justificación es bien distinta en cada caso.

En un sentido lato, con escaso relieve constitucional, comisión parlamentaria significaría cualquier grupo reducido que, emanado del Parlamento, estaría ligado a éste mediante una relación de incidencia representativa limitada. En términos más estrictos, el sentido técnico tradicional de una comisión parlamentaria tenía como parámetro justificativo la función que le caracterizaba históricamente, esto es, la instrucción o preparación para la actividad posterior del Pleno. De este modo es oportuno recordar la clásica definición de BARTHÉLEMY para quien las comisiones eran «organismos constituidos en cada Cámara, compuestos por un número ge-

1 Esta es la postura mantenida en mi Tesis doctoral sobre la Diputación permanente en las Cortes en la historia del régimen constitucional español leída en 1990 en la Facultad de Derecho de la Universidad Complutense de Madrid. 
neralmente limitado de sus miembros... y encargados en principio de preparar su trabajo normalmente mediante la presentación de un informe» ", aclarando todavía más esta idea SÁNCHEZ AGESTA al señalar que las comisiones tienden a preparar ese trabajo de la Camara «pero no a sustituirla» ${ }^{3}$.

Será precisamente este último objetivo la causa de la creación de un ente diferenciado en el esquema parlamentario que se ocupe de garantizar la continuidad de las modernas Asambleas que si bien son permanentes por su reconocimiento constitucional para mantener viva la idea de representación, son discontinuas debido a la limitación material y, por tanto, temporal de su funciones materializada en la interrupción de los trabajos regulares de las Cámaras, bien por causas naturales (vacaciones parlamentarias), bien por causas jurídicas (disolución, ya automática o anticipada, y antigua facultad regia de suspensión de sus sesiones). Es decir, la Diputación permanente no es un delegado del Pleno por razones de división racional del trabajo parlamentario sino que suple a la Cámara con total sustantividad en los momentos en que aquéllas se encuentren en receso. No es, desde luego, ésta la única tesis defendida por la doctrina, hablándose por ello de la Diputación permanente como mera comisión ${ }^{4}$, como «Comisión especial» ${ }^{5} 0$ "comisión sui generis» ${ }^{6}$.

Son, sin embargo, los rasgos específicos de la Diputación permanente -origen constitucional, fijación temporal de su funcionamiento, autonomía funcional respecto al Pleno, etc.- las que obligan a diferenciarla con claridad de las comisiones parlamentarias ya sean ordinarias o especiales, aunque las meras coincidencias formales con la composición de las comisiones permanentes y el ocasional reenvío reglamentario a las normas propias reguladoras de éstas para disciplinar la Diputación permanente pudieran ofrecer argumentos para defender lo contrario en un análisis apresurado. Tampoco anula la idea aquí defendida ${ }^{7}$ el creciente significado de las comisiones como instrumento de agilización del quehacer

2 BARTHÉLEMY, Joseph: Essay sur le travail parlementaire et le système des commissions. Librairie Delagrave, París 1934, pág. 10.

3 SÁnchez Agesta, Luis: Voz «Comisiones Parlamentarias", en Nueva Enciclopedia Juridica, tomo IV, Seix, Barcelona 1981, pág. 453.

4 Alzaga Villaamil, Óscar: La Constitución Española de 1978. Comentario sistemático. Ed. del Foro, Madrid 1978, pág. 527

s Entre otros, Álvarez CONDE, Enrique: El régimen politico español, 4. "ed., Tecnos, Madrid 1990, pág. 410.

6 PÉREz DoBÓn, Juan José: «Les activités parlementaires après la dissolution de la Chambre: la "Diputation permanente" espagnole", en Informations Constitutionnelles et Parlementaires, 1. a série, n. ${ }^{\circ} 137$, Genève 1984, pág. 27.

7 En contra de PECES BARBA, para quien “la Diputación permanente tiene una estructura similar a la de una comisión legislativa permanente», $D S C D$, año 1979, n. ${ }^{\circ}$ 1. Diputación permanente. Sesión 18 de enero de 1979, pág. 16. 
de las Cámaras que produce en la actualidad una mutación en sus relaciones con el Pleno viéndose en ocasiones capacitadas -recuérdese el artículo 75.2 de nuestra actual Constitución- para adoptar decisiones que en un principio corresponderian a la Asamblea en su conjunto. Esa labor de carácter legislativo nada tiene que ver con la autonomía reconocida a nivel constitucional a la Diputación permanente como órgano encargado de garantizar la continuidad parlamentaria en los momentos en los que la actividad ordinaria de la Cámara está interrumpida.

Sentada la naturaleza propia de las comisiones y de la Diputación permanente, el tratamiento que se propone es la diferenciación bibliográfica de ambas figuras. Respecto a la ordenación y criterios a la hora de seleccionar las obras se obvia cualquier sentido localista que hubiera restringido la materia al ámbito del parlamentarismo español. Bien al contrario, se ha estimado aconsejable ampliar las referencias al Derecho comparado con el doble propósito de ofrecer un caudal de información más amplio y demostrar, especialmente en el caso de las comisiones, que estas figuras no son exclusivas de nuestro entorno político más próximo sino que son instituciones prácticamente generalizadas en cualquier cultura juridica. El panorama hay que matizarlo respecto a la Diputación permanente, sistema de continuidad parlamentaria de raíz española y con una proyección actual restringida en el Derecho comparado, a lo que se añade la dificultad para encontrar estudios especificos sobre ella al margen de referencias puntuales en obras de alcance más global. Esta última peculiaridad explica otra de las orientaciones metodológicas utilizadas. En efecto, como criterio básico hay que decir que sólo se han tenido en cuenta los estudios directamente relacionados con el punto a tratar en cada caso sin citar aquellos análisis, generalmente manuales o comentarios generales, en los que se hacían alusiones ocasionales no exhaustivas. Esta práctica solamente se ha roto en relación a aquellos países en los que no se encuentran monografías específicas, prefiriendo dar noticia de tales instituciones como muestra de la generalización ya apuntada.

\section{A. COMISIONES PARLAMENTARIAS}

Es ya clásico reseñar la necesidad de estos órganos en las modernas Asambleas ${ }^{8}$ para asegurar la flexibilidad y agilidad de su labor. Se-

8 Pérez Serrano las calificó de «rueda principalísima en la mecánica parlamentaria» (Pérez Serrano, Nicolás: Tratado de Derecho Político. Civitas, Madrid 1976, pág. 762). Apuntan también esta importancia, v. gr. ColliARD, Jean Claude: Les régimes parlementaires contemporains. Presses de la Fondation Nationale des Sciences Politiques, Paris 1978, pág. 241; LAVEgne, Bernard: Pour un régime parlementaire rénové. Presses Universitaires de France, Paris 1974, pág. 53, etc. 
ñalaba por ello Ivo RENS que un Parlamento es "un órgano demasiado grande y sobre todo demasiado pesado para poder resolver las cuestiones que le son sometidas si no son anteriormente objeto de un examen por algunos de sus miembros según un procedimiento abreviados ${ }^{9}$. No es extraño, por tanto, que surgieran en el régimen liberal como órgano interno de trabajo parlamentario a modo de etapa inicial del procedimiento legislativo, a la vez que se pretendía, como apunta RUBIO LLORENTE, hacer que los parlamentarios se especializasen en materias determinadas y "crear ámbitos en donde sea posible la negociación dentro del Parlamento, pero sin publicidad" ${ }^{10}$.

Aun teniendo por ciertas las ideas anteriores es preciso relativizar el significado de las comisiones en los origenes del sistema representativo decimonónico. Éste se caracterizaba primordialmente por el sentido individual de la acción parlamentaria y por el papel nuclear del Pleno en su organización y desarrollo. La débil estructura inicial de los partidos hacian del parlamentario el sujeto básico del trabajo que se plasmaba materialmente en su actuación ante el Pleno, convertido así en el eje decisorio de la Cámara. En la actualidad, por el contrario, esa labor individual ha dado paso a un actividad colegiada, canalizada a través de los grupos parlamentarios y que se refleja en la aparición o desarrollo de órganos internos de las Asambleas, lo que ha dado en llamarse «creciente policentrismo de la actividad parlamentaria" ${ }^{11}$, cuya trascendencia dista mucho de la antigua función instructora de las primitivas comisiones. En este nuevo modelo destacan con luz propia las modernas comisiones parlamentarias, consideradas incluso como los órganos ordinarios de realización del trabajo de las Cámaras ${ }^{12}$. Hay, efectivamente, un acuerdo generalizado ${ }^{13}$ sobre la conveniencia de desbordar su antigua dependencia funcional respecto al Pleno, asegurándoles una autonomía al más alto nivel incluyendo el reconocimiento de su plena capacidad decisoria, tendencia recogida ya en el Derecho comparado.

9 ReNS, Ivo: «Les Commissions parlementaires en Droit comparé», en Revue International de Droit Comparé, n. 2 , 1961, pág. 309.

to Rubio LloRENTE, Francisco: «Los poderes del Estado», en España: un presente para el futuro. 2 Las Instituciones. Instituto de Estudios Económicos, Madrid 1984, pág. 63.

11 Cazorla Prieto, Luis Maria: «Problemas de la organización y el funcionamiento de los Parlamentos actuales", en El Parlamento y sus transformaciones actuales. Jornadas organizadas por la Asamblea Regional de Murcia. Ángel Garrorena Morales (editor), Tecnos, Madrid 1990, pág. 340.

12 Solé Tura, Jordi, y Aparicio Pérez, Miguel Ángel: Las Cortes Generales en el sistema constitucional español. Tecnos, Madrid 1984, pág. 147.

${ }_{13}$ Asi lo reconoce VILLACORTA MANCEBO, Luis: Hacia el equilibrio de poderes. Comisiones legislativas y robustecimiento de las Cortes. Secretariado de Publicaciones, Universidad de Valladolid, Valladolid 1990, págs. 23-24. 


\section{Derecho comparado}

La existencia de las comisiones es un dato común a la mayoria de los Parlamentos ${ }^{14}$. Naturalmente, las caracteristicas de su organización y la importancia de su cometido han variado de unos sistemas a otros, pero el hecho cierto de su funcionamiento ha sido motivo de inquietud para la doctrina dando lugar a una realidad abrumadora de producción científica. Esta es la razón de que en esta sede se recojan, salvo las excepciones anteriormente mencionadas, los estudios específicos y no las menciones de obras generales. Lógicamente se hace alusión a los análisis comparativos a modo de visión de conjunto como reflejo de la amplitud del fenómeno en todos los modelos parlamentarios.

a) Estudios generales y de Derecho comparado

Association of Secretaries of Parliaments. Parliamentary Committees. Rapporteur R. Pauwels, en Constitutional and Parliamentary information, n. ${ }^{\circ} 23,1955$, págs. 153-254.

Association of Secretaries of Parliaments. The system of parliamentary committees; en Constitutional and Parlamentary information, $1973, \mathrm{n} .{ }^{\circ} 93$, págs. 3-50.

Brigaud: Les Commissions parlementaires en France, en Angleterre et aux Etats Unis, 1920.

Drion, F.: La procédure des autions dans les commissions parlementaires del pays du Benelux. Bruxelles, Centre de Recherche et d'Information Socio-Politiques, 1978.

EUFEMIA, G.: "Le commissioni parlamentare nelle costituzioni moderne», en Rivista trimestrale di Diritto Pubblico, n. ${ }^{\circ} 1,1956$, págs. 16-53.

ELIA, Leopoldo: “Commissioni parlamentari», en Enciclopedia del Diritto, vol. VII. Milán 1960, págs. 895 y ss.

Furlani, S.: Le commissioni parlamentari d'inchiesta. Giuffrè, Milán 1954.

14 Rens, Ivo, op. cit., pág. 309. Solé y Aparicio hablan de “una de las manifestaciones más antiguas de la organización parlamentaria" (SOLE TURA, Jordi, y Aparicio Pérez, Miguel Ángel, op. cit., pág. 161). 
HuRlgurt, William: Law Reform Commissions in the United Kingdom, Australia and Canada. Edmonton, Juriliber, 1986.

MARSH, Norman: "Law Reform Commissions Compared: A Review Article», en International and Comparative Law Quarterly, vol. 38, 1989, páginas 185-196.

MiLlaR, David: «Treatment of European Community matters by committees of the national Parliaments", en Herman, V., y Schendelen, R.: The European Parliament and the national Parliament. Westmead, Saxon House, 1979 , págs. $189-200$.

Pauwels, R:: «Le Commissioni Parlamentari en la sesión de Helsinki de la Unión Interparlamentaria", Bolletino d'informazioni costituzionali e parlamentari, VIII, Roma 1957.

ReIneRt, Harri: Vermittlungsausschuss und Conference Committees. Heidelberg, Winter, 1966, págs. 41-80.

RENS, Ivo: “Les Commissions parlementaires en Droit comparé», en Revue International de Droit comparé, n. ${ }^{\circ} 2$, 1961, págs. 309-326.

SÁNCHEZ Agesta, Luis: «Comisiones parlamentarias", en Nueva Enciclopedia Juridica, Seix, vol. IV, Barcelona 1952, págs. 453-454.

SHAW, Malcomm y LEES, John: «Commissioni legislative e sistema político», en Rivista italiana de scienza política, n. ${ }^{\circ}$ 1, 1974, págs. 165-195.

Committees in legislatures: A comparative Analisys. Edited by John D. Lees and Malcolm Shaw, Duke University Prees, 1979.

WING, M. y HAGER, M.: Committees in the European Parliament and Committees in national Parliament: a comparative perspective. Paper prepared for the ECPR, Workshops in Grenable, 1978.

\section{b) Estados Unidos}

Es tal vez el país donde el sistema de comisiones se ha desarrollado con mayor vigor. La estructura de poder norteamericana, basada en una rígida separación de los poderes, acentuó la autonomia organizativa del Congreso, potenciando desde un primer momento la capacidad de las comisiones como instrumento básico de trabajo hasta el punto de que FRAGA considera que cen el sistema congresional norteamericano las comisiones 
son lo más importante» ${ }^{15}$, impresión confirmada por el dato de que las comisiones americanas llevan a cabo la mayor parte de todo el trabajo del Congreso en materia legislativa ${ }^{16}$.

El sistema americano de comisiones quedó sustancialmente modificado en virtud de la reforma operada por la Legislative Reorganization Act de 1946 y completada por la Legislative Reorganization Act de 1970. Por ellas se redujo de forma considerable el número de las comisiones que han mantenido la tradición de dividirse en subcomisiones y que trabajan como comisiones permanentes especializadas, junto a las que se denota la existencia de comisiones de investigación, de comisiones especiales mixtas ${ }^{17}$ o de la comisión, heredada del ejemplo inglés, de toda la Cámara (Committee of the Whole).

Parliamentary Opinions. The Opinions Committee Parliamentary Journal, American Institute of Parliamentarians, Fort Wayne, Indiana 1989, volumen XXX, n. ${ }^{\circ}$, págs. 31-54.

AsHeR, Herbert B.: "Committees and the norm of specialization», The Annals of the American Academy of Political Science, 1974, n. ${ }^{\circ} 411$, páginas 63-74.

AtTINA, Fulvio: «Le commissioni parlamentari affari esteri: una unità decisionale in politica estera», la Rivista italiana di scienza politica, 2 (1972), n. ${ }^{\circ} 3$, págs. $615-628$

BERG, John: "The effects of seniority reform on three House committees in the 94th Congress", en RIESELBACH, L. N.: Legis/ative reform. Lexington, Mass., Lexington Books, 1978, págs. 49-59.

Bıввy, J. F.: «Committee characteristics and legislative oversight of administration", Midwest journal of political science, 10 (1966), n.. 1, páginas $78-98$.

15 Fraga Iribarne, Manuel: La reforma del Congreso de los Estados Unidos. Ediciones Cultura Hispánica, Madrid 1951, pág. 205. Se ratifica así la opinión de Woodrow Wilson para quien "el Congreso en sus reuniones de comisiones es el Congreso operante" (WILSON, Woodrow: Congressional Government, trad. Adolfo Posada, La España Moderna, Madrid (s. f.), pág. 65.

${ }^{16}$ Cuantificado en alguna ocasión en el 90 por 100, Tunc, A. et S. Tunc: Le système constitutionnel des Etats-Unis d'Amérique, tomo II, Éditions Domat Montchrestien, Paris 1954, pág. 57.

17 Zinn, C. J.: American Congressionnal Procedure. West Publishing Company, Minnesota 1957, pág. 41 
Bolling, Richard: "Committees in the House", The Annals of the American Academy of Political and Social Sciences, 1974, n. ${ }^{\circ} 411$, págs. 1-14.

Bond, Jon R.: “Olling the Tax Committees in Congress, 1900-1974: Subgovernment theory, the over representation hypothesis, and the oil depletion allowance», en American Journal of Political Science, 23 (1979), n. ${ }^{\circ} 4$, págs. $651-664$.

Bone, Hugh A.: «The Capitol Hill Committees», Parliamentary affairs, 9 (1956), n. ${ }^{\circ} 4$, págs. $388-397$.

Braunthal, Gerard: «Der Aussenpolitische Ausschuss des amerikanischen Senats und seine öffentlichen Anhörungen», reitschrift für Parlamentsfragen, 2 (1971), n. ${ }^{\circ}$, págs. 483-497.

BRENNER, Philip: "Committee conflict in the congressional arena", The Annals of the American Academy of Political and Social Sciences, 1974, n. ${ }^{\circ} 411$, págs. $87-101$.

Brock, Bill: "Committee in the Senate", The Annals of the American Academy of Political and Social Sciences, 1974, n. ${ }^{\circ} 411$, págs. 15-16.

BUDGET committees: committees at center of 1979 Budget fight, Congressional Quarterly guide to current American Government, 1979, Fall, páginas 5-12.

BULlock III, Ch. S.: "Apprenticeship and committee assignments in the House of Representatives", Journal of politics, 32 (1970), n. ${ }^{\circ} 3$, págs. 717-720.

-: "Committee transfers in the United States House of Representatives", Journal of politics, 35 (1973), n. ${ }^{\circ}$, págs. 85-120.

-: «Freshman Committee assignments and re-election in the United States House of Representatives", American Political Science Review, 66 (1972), n. ${ }^{\circ}$, págs. 996-1007.

-: "The influence of state party delegation on House committee assignments", Midwest journal of political science, 15 (1971), n. ${ }^{\circ} 3$, páginas 525-546.

-: «Motivations for US congressional committee preferences: freshmen of the 92nd Congress, Legislative studies quarterly, 1 (1976), n. ${ }^{\circ}$, páginas 201-212.

CASPER, Gerhard: "The Committee system of the United States Congress", American journal of comparative law, 26 (1978), supplement, páginas 359-376. 
CAsstevens: «The Committee Function: An Influence Equation», en American Political Science Review, 1972.

CLARK, Roger S.: «Human rights and the U.N. Committee on Crime Prevention and Control", en The Annals of the American Academy of Political and Social Sciences. Philadelphia 1989, n. $^{\circ} 506$, págs. 68-84.

Collie, Melissa; Cooper, Joseph: «Multiple referral and the 'new' committe system in the House of Representatives", en Congress reconsiderey. Edited by Lawrence C. Dood, Bruce I. Oppenheimer. Washington 1989, XIII, págs. 245-305.

A Cомmiтtee profile: Senate Finance - the fiefdom of Russel Long, Congressional Quarterly guide to current American Government, 1978, Spring, págs. 25-35.

Crouzatier, J. M.: “Le rôle des commissions d'enquête du Congrès des EtatsUnis, Revue du Droit Public et de la Science Politique, 91 (1975) n. ${ }^{\circ} 4$, págs. 997-1053.

Congressional Quarterly. Committees and subcommittees of the 96th Congress. Washington, D.C., 1979; 54 páginas (Weekly reports, supplement to vol. 37, n. $^{\circ} 15$, April 14, 1979).

Congressional Quarterly. Committees and subcommittees of the 97th Congress. Washington, D.C., 1981; 54 páginas (Weekly reports, supplement to vol. 39, n. ${ }^{\circ} 13$, March 28, 1981).

DAVIDSON, R. H.: «Representation and congressional committees», The Annals of the American Academy of Political and Social Sciences, 1974, n. ${ }^{\circ}$ 411, págs. $48-62$.

Davidson, Roger H.: "Two avenues of change: House and Senate committee reorganization, en: DodD, L. C., \& B. I. OPPENHEIMER: Congress reconsidered, 2nd ed. Washington, D. C., Congressional Quarterly Press, 1981; págs. 107-133.

DODD, Laurence C.: "Committee integration in the Senate: a comparative analysis", Journal of Politics, 34 (1972), n. ${ }^{\circ}$ 4, págs. 1135-1171.

Draper, Frank D., \& Bernard T. Pitsvada: “Congress and executive branch budget reform: The House Appropriations Committee and zerobase budgeting", en International Journal of Public Administration, 2 (1980), n. ${ }^{\circ} 3$, págs. $331-374$.

Drsson, J. W. \& J. W. Soulz: «Congressional committee behavior on roll-call votes: the US House of Representatives, 1955-1964", Midwest Journal of Political Science, 14 (1970), págs. 626-647. 
ENTIN, Kenneth: «Information exchange in Congress: the case of the House Armed Services Committee", en Western Political Quarterly, 26 (1973), n. ${ }^{\circ} 3$, págs. $427-439$.

FAIRLIE, "Commissions et Commités législatifs aux Etats Unis", en Annuaire de l'Institut International du Droit Public, 1933, págs. 43 y ss.

FARnsworth, David Nelson: The Senate committee on foreign relations. Urbana, The University of Illinois Press, 1961.

Fenno, Richard F.: Congressmen in committees. Boston, Little, Brown, 1973.

FEIG, Douglas G.: «Partisanship and integration in two House committees: Ways and Means and Education and Labor", en Western Political Quarterly, 34 (1981), n. ${ }^{\circ} 3$, págs $426-437$.

-: «The stability of congressional committees: A formal analysis», en Political Methodology, 6 (1979) n. ${ }^{\circ}$ 3, págs. 311-342.

Fenno, R. F.: «The House Appropriations Committee as a political system: the problem of integration», en HIRSCH \& HaNCOCK: Comparative legis/ative systems. New York, The Free Press, 1971, págs. 222-244.

- : :The House Appropriations Committee as a political system: the problem of integration", American Political Science Review, 56 (1963), n. ${ }^{\circ}$, págs. 310-324.

Fenno, Richard F. Jr.: "The Appropriations Committee as a political system», en PEABOdY, R. L., \& N. W. Polsby: New perspectives on the House of Representatives. Chicago, Rand McNally College Publishing Company, 1977, págs. 139-166.

-: "The House Appropriations Committee as a political system: The problem of integration, en WOLFINGER, R. E.: Readings on Congress. Englewood Clifís, N. J., Prentice-Hall, 1971, págs. 132-157.

-: "The House Committee on Education and Labor", en WolfINGER, R. E.: Readings on Congress. Englewood Cliffs, N. J., Prentice-Hall, 1971, págs. 180-197.

FEREJOHN, John: "Who wins in conference Committee?" en Journal of Politics, 37 (1975), n. ${ }^{\circ}$, págs. 1033-1046.

Fiorina, M. P., \& Charles R. Plott: «Committee decision under majority rule: an experimental study", en American Political Science Review, 72 (1978), n. ${ }^{\circ} 2$, págs. 575-595. 
FOWLER, L. L., et al.: «The electoral effects of House committee assignments", en Journal of Politics, 42 (1980), n. ${ }^{\circ}$, págs. 307-319.

Fox, D. M., \& C. H. CLAPP: «The House Rules Committee and the programs of the Kennedy and Johnson administrations, Midwest Journal of Political Science, 14 (1970), n. ${ }^{\circ} 4$, págs. 667-672.

Freeman, J. Leiper: The political process, Executive bureau-legislative committee relations. New York, Random House, 1966.

Fuentealba Rollat, Janett: «Naturaleza y facultades de las comisiones investigadoras del Congreso de los Estados Unidos en relación con la primera enmienda de la Constitución», Revista de Derecho Público, 1976, n. $^{\circ} 19-20$, págs. 33-61.

Galloway, G. B.: "Development of the Committee System in the House Representatives", en American Historical Review, octubre 1959, págs. 17 y ss.

GaWTHROP, Louis C.: «Changing membership patterns in House committees», American Political Science Review, 60 (1966), n. ${ }^{\circ} 2$, págs. 366-373.

Gilligan, Thomas W., y Krebiel, Keith: "Asymmetric Information and Legislative Rules with a Heterogeneous Committee», en American Journal of Political Sciences, University of Texas, vol. $33, n .{ }^{\circ} 2,1989$, págs. 459490.

Goodwin: «Subcommittees: The Miniature Legislatures of Congress», en American Political Sciences Review, 1962, págs. 128-143.

Goodwin, George: The little legis/atures. Committees of Congress. Amherst, University of Massachussetts Press, 1970.

GouLD, James W.: «The origins of the Senate Committee on Foreign Relations, 1789-1816», en Western Political Quarterly, 14 (1959), págs. 670-682.

GREIG, D. W.: «Forum State Jurisdiction and Sovereign Inmunity under the International Law Commissions Draft Articless, en International and Comparative Law Quartely. London, 1989, vol. 38, part. 2, págs. 243276.

Gross, Donald A.: "Conference committees, sophisticated voting, ando cyclical majorities", en Legis/ative Studies Quarterly, 4 (1979), n. ${ }^{\circ}$, páginas 79-94.

GuTH, James L.: «Committee socialization in the US House of Representatives», en Journal of Political Science, 6 (1979), n. ${ }^{\circ} 2$, págs. 107-118. 
HaEberle, Steven H.: "The institutionalization of the subcommittee in the United States House of Representatives", en Journal of Politics, 40 (1978), n. ${ }^{\circ}$, págs. 1054-1065.

HALL, Richard L.: «Partticipation and Purpose in Committee Decision Making», en American Political Science Review. Washington, 1987 (I), páginas 105-127.

-: "Committee decision making in the postreform Congress", en Congress reconsidered. Edited by Lawrence C. Dodd, Bruce I. Oppenheiner. Washington 1989, XIII, págs. 197-223.

Henderson, Thomas A.: Congressional oversight of Executive agencies. A study of the House Committee on Government Operations. Gainesville, University of Florida Press, 1970, pág. 74.

Henderson, D. G.: «The Senate Foreign Relations Committee», en Washington Quarterly, 2 (1979), n.⒉ págs. 3-12.

Hess, Beth B.: «How the saved the Special Committee on Aging", en Society, 15 (1978), n. ${ }^{\circ}$, págs. 56-58.

Horn, Stephen: Unused power. The work of the Senate Committee on Appropriations. Washington, The Brookings Institution, 1970.

JAHNICE, Thomas R.: "The congressional committee system and the oversight process: Congress and NASA», en Western Political Quarterly, 21 (1968), n. 2 , págs. 227-239.

Jameson, John F.: The Origen of the Standing Committee System in American Legislative Bodies. Washington 1894.

Jewell, M. E., \& ChY CHI Hung: «Membership movement and committee attractiveness in the US House of Representatives", American Journal of Political Science, 18 (1974), n. ${ }^{\circ}$ 2, págs. 433-442.

JONES, Charles O.: «The Agriculture Committee and the problem of representation», en PeABOdy, R. L., \& N. W. PolsBy: New perspectives on the House of Representative. Chicago, Rand McNally College Publishing Company, 1977, págs. 167-185.

-: "Between party battalions and committee suzerainty», en The Annals of the American Academy of Political and Social Sciences, 1974, n. ${ }^{\circ} 411$, págs. 158-168.

-: "Representation in Congress: the case of the House Agriculture Committee», American Political Sciencie Review, 55 (1961), n. ${ }^{\circ}$ 2, págs. 358367. 
KAISER, Fred M.: “Congressional change and foreign policy: The House Committee on International Relations", en RIESELBACH, L. N.: Legis/ative reform. Lexington, Mass., Lexington Books, 1978, págs. 61-71.

KAISER, Fred: "Oversight of foreign policy: the US House Committee on International Relations", en Legis/ative Studies Quarterly, 2 (1977), n. ${ }^{\circ} 3$, págs. 255-279.

Kaplan, Lewis A.: «The House Un-American Activities Committee and its opponents: a study in congressional dissonance», en Journal of politics, 30 (1968), págs. 647-671.

Kravitz, Walter: "The influence of the House Rules Committee", en Joseph S. CLARK, ed., Congressional Reform, New York, Crowell, 1965, páginas $127-137$.

-: “The US congressional committee system», en The Parliamentarian, 60 (1970), n. ${ }^{\circ} 3$, págs. 121-128.

-: “Evolution of the Senate's committee system», en The Annals of the American Academy of Political and Social Sciences, 1974, n. 411 , páginas 27-38.

Krehbiel, Keith, y Rivers, Douglas: "The Analysis of Committee Power: An Application to Senate Voting on the Minimum Wage", en American Journal of Political Science, University of Texas, vol. 32, n. ${ }^{\circ} 4,1989$, págs. 1151-1174.

LEES, John D.: “Committees in the United States Congress", en LEES, J. D., \& M. SHaw: Committees in legislatures: a comparative analysis, Durham, N. C., Duke University Press, 1979, págs. 11-60.

-: "Committees reform in the US Congress - a progress report", en Journal of parliamentary information, 20 (1974), n. ${ }^{\circ}$, págs. 553-560.

-: The committees system of the United States Congress. London, Routledge \& Kegan Paul, 1967.

-: «Committees of Congress. A comparative evaluation», en Capitol Studies, 3 (1975), n. ${ }^{\circ} 1-2$, págs. 5-12.

LELoup, Lance T.: «Process versus policy: the US House Budget Committee», en Legislative Studies Quartely, 4 (1979), n.², págs. 227-254.

LEWIS, Anne L.: «Floor success as a measure of committee performance in the House», en Journal of Politics, 40 (1978), n. ${ }^{\circ} 2$, págs. 460-467. 
LEWIS, Eleanor G.: «The House Committee on Rules and the legislative program of the Kennedy and Johnson administrations", en Capitol Studies, $6(1978), n^{\circ} 2$, págs. $27-38$.

LowE, David E.: “The Bolling Committee and the politics of reorganization", en Capitol Studies, 6 (1978), n.¹, págs. 39-61.

LÜTZKER, P.: «The behavior of Congressmen in a committee setting: a research report», en Journal of Politics, 31 (1969), n. ${ }^{\circ}$, págs. 140-166.

MaLbIN, M. J.: "Congressional committee staffs: who is in charge here?", en Public Interest, 1977, n. ${ }^{\circ} 47$, págs. 16-40.

MANLEY, J. F.: “The House Committee on Ways and Means: Conflict management in a congressional committee", en WolfINGER, R. E.: Readings on Congress. Englewood Cliffs, N. J., Prentice-Hall, 1971, págs. 158179.

--: The politics of finance. The House Committee on Ways and Means. 'Boston, Little, Brown, 1970.

Marshall, E. Dimock: Congressional investigating Committees. Baltimore 1929.

MARVIN, Keith E.: «Evaluation for congressional committees. The quest for effective procedures", en ZWEIG, F.: Evaluation in legislation. Beverly Hills, Sage Publication, 1979, págs. 45-56.

Masters, Nicholas A.: "Committee assignments in the House of Representatives", en WOLFINGER, R. E.: Readings on Congress. Englewood Cliffs, N. J., Prentice-Hall, 1971, págs. 109-131.

--: "Committee assignments in the House of Representatives", en American Political Science Review, 55 (1961), n. ${ }^{\circ}$ 2, págs. 345-357.

MCClintock, Charles C.: “A program review and evaluation system: Framework for congressional committees", en ZWEIG, F.: Evaluation in legislation. Beverly Hills, Sage Publication, 1979, págs. 103-120.

McConachie, L. G.: Congressional Committees. New York 1898.

McCrown, Adams C.: The Congressional Conference Committee, New York 1927.

MILLER, Susan H.: «Congressional committee hearings and the media: Rules of the game", en Journalism Quarterly, 55 (1978), n. ${ }^{\circ}$, págs. 657-663. 
Morrow, William L.: Congressional committees. New York, Scribner, 1969.

NeLSON, Garrison: «Assessing the Congressional Committee System: contributions from a comparative perspective", en The Annals of the American Academy of Political and Social Sciences, 1974, n. ${ }^{\circ} 411$, págs. 120-132.

Nevins, Allan: "The development of the committee system in the American Congress", en Parliamentary affairs, 3 (1949), n. ${ }^{\circ}$ 1, págs. 136-146.

NEw effort to reorganize House Committees. Congressional Quarterly guide to current American Government, 1979, Fall, págs. 15-16.

OPPENHEIMER, B. I.: «Policy implications of Rules Committee reforms», en RIESELBACH, L. N.: Legislative reform. Lexington, Mass., Lexington Books, 1978, págs. 91-104.

-: "The Rules Committee: New arm of leadership in a decentralized House», en Dodd, L., \& B. I. OpPenheImer: Congress reconsidered. New York, Praeger, 1977, págs. 96-116.

Ornstein, Norman J.: "Causes and consequences of congressional change: subcomittee reforms in the House of Representatives, 1970-1973", en Congress in change. New York, Praeger, 1976; págs. 88-114.

Ornstein, N. J., \& D. W. Rohde: «Shifting forces, changing Rules and political outcomes: The impact of congressional change on four House committees", en PEABOdY R. L., \& N. W. Polsby: New perspectives on the House of Representatives. Chicago, Rand McNally College Publishing Company, 1977, págs. 186-269.

-: «Revolt from within: congressional change, legislative policy and the House Commerce Committee», en WELCH, S., \& J. G. PeTERS: Legislative reform and public policy. New Yord, Praeger, 1977, págs. 54-72.

Ostrom, Donald: "Consensus and conflict in the House: a revised look at the Ways and Means and Education and Labor Committees", en Polity, 11 (1979) $n .{ }^{\circ} 3$, págs. 430-439.

OXENDALE, James R., Jr.: «Membership stability on standing committees in legislative lower Chambers", State Government, 54 (1981), n. ${ }^{\circ} 4$, páginas 126-129.

PARKER, Glenn R.: "The selection of committee leaders in the House of Representatives", American Politics Quarterly, 7 (1979), n. ${ }^{\circ} 1$, páginas 71-93. 
ParRIS, Judith $H_{.:}$“The Senate reorganizes its committees, 1977», Political Science Quarterly, 95 (1979), n.², págs. 319-337.

Patterson, S. C.: "The professional staff of congressional committees", $A d$ ministrative Science Quarterly, 15 (1970), March, págs. 22-37.

-: "Congressional committee professional staffing: capabilities and constraints", en KeRnBerg \& Musolf: Legis/atures in developmental perspective. Durham, Duke University Press, 1970, págs. 391-428.

PeABOdY, Robert L.: “Committees from the leadership perspective», The Annals of the American Academy of Political and Social Sciences, 1974, n. ${ }^{\circ} 411$, págs. 133-146.

-: "The Enlarged Rules Committee», en Robert L. Peabody and Nelson W. Polsby, eds: New Perspectives on the House of Representatives, Chicago, Rand-McNally, 1963, chap. 6.

Perkins, Lynette P.: alnfluences of Members' goals on their committee behavior: The U.S. House Judiciary Committee», Legis/ative Studles Quarterly, 5 (1980) n. ${ }^{\circ}$ 3, págs. 373-392.

PrICE, David E.: «Policy making in congressional committees: the impact of "environmental" factors», en American Political Science Review, 72 (1978), n. ${ }^{\circ} 2$, págs. $548-574$.

PRICE, Douglas: «Careers and committees in the American Congress: the problem of structural change", en AYDELOTTE, W. O.: The history of parliamentary behavior. Princeton, N. J., Princeton University Press, 1977, págs. 28-62.

PrICE, David E.: “Congressional committees in the policy process», en DodD, L. C., \& B. I. OppenheImer: Congress reconsidered, 2nd ed. Washington, D. C., Congressional Quarterly Press, 1981, págs. 156-185.

- : "The impact of reform: The House Commerce Subcommittee on Oversight and Investigations", en RIESELBACH, L. N.: Legis/ative reform. Lexington, Mass., Lexington Books, 1978, págs. 133-157.

Price, D.: Who makes the laws? Creativity and power in Senate committees. Cambridge, Mass., Schenkman, 1972.

Ralph Nader Congress Project: The Money Committees, Nueva York 1975

—: The Revenue Committees, Nueva York 1975. 
Ralph Nader Congress Project (varios autores): The Environment Committees, Nueva York 1975.

-: Equipo dirigido por Schuch: The Judiciary Committees. A Study of the House and Senate Judiciary Committees. Nueva York 1975.

RAY, B. A.: «The responsiveness of the U.S. Congressional Armed Services Committees to their parent bodies", en Legislativo Studies Quarterly, 5 (1980), n. ${ }^{\circ} 4$, págs. 501-515.

-: «Federal spending and the selection of committee assignments in the U. S. House of Representatives, en American Journal of Political Science, $24(1980), n .{ }^{\circ} 5$, págs. 494-510.

RiESELbACH, L. N., \& Joseph K. UnEKIS: "Ousting the oligarchs: Assessing the consequences of reform and change in four House committees", en Congress and the presidency: A journal of capital studies, 9 (1981-82), n. ${ }^{\circ} 1$, págs. $83-118$.

RITT, L. C.: "Committee position, seniority, and the distribution of Government expenditures", Public policy, 24 (1976), n. ${ }^{\circ}$ 4, págs. 463-489.

Robinson, J. A.: “Decision-making in the House Rules Committee», Administrative Science Quarterly, 3 (1985), June, págs. 73-86.

—: The House Rules Comittee. Indianapolis, Bobbs-Merrill, 1963.

-: "The role of the Rules Committee in arranging the program of the US House of Representatives», Western Political Quarterly, 12 (1959), págs. 633-669.

-: "The role of the Rules Committee in regulating debate in the US House of Representatives», Midwest Journal of Political Science, 5 (1961), págs. 59-69.

RoHDE, David W.: "Committee reform in the House of Representatives and the Sub-Committee Bill of Rights", en The Annals of the American Academy of Political and Social Sciences, 1974, n. ${ }^{\circ} 411$, págs. 39-47.

RoHDE. D. W., \& Kenneth A. ShePsLE: «Democratic committee assignments in the House of Representatives: strategic aspects of a social choice process", American Political Science Review, 67 (1973) n. ${ }^{\circ} 3$, págs. 889905.

-: "Committee assignments", en Peabody, R. L., \& N. W. Polsby: New perspectives on the House of Representatives. Chicago, Rand McNally College Publishing Company, 1977, págs. 295-323. 
RUDDER, Catherine E.: "Committee reform and the revenue process", en DodD, L., \& B. I. OpPENHEIMER: Congress reconsidered. New York, Praeger, 1977, págs. $117-139$.

RUdDER, Catherine: «The policy impact of reform of the Committee on Ways and Means», en RIESELBACH, L. N.: Legislative reform. Lexington, Mass., Lexington Books, 1978, págs. 73-89.

RusseLL, Mary: "The Press and the committee system", en The Annals of the American Academy of Political and Social Sciences, $1974, n .{ }^{\circ} 411$, páginas 114-119.

SCHER, S.: “Congressional committee members as independent agency overseers: a case study", American Political Science Review, 54 (1960), págs. $911-920$.

Sharkansky, I.: "An Appropriations Sub-Committee and its client agencies: a comparative study of supervision and control", American Political Science Review, 59 (1965), págs. 622-628.

Senate approves committee changes, Congressional Quarterly guide to current American Government, 1977, Fall, págs. 47-53.

--: Congressional Quarterly guide to current American Government, 1978, Spring, págs. 18-24.

Stanga, John E., Jr., \& David N. Farnsworth: "Seniority and Democratic reforms in the House of Representatives: Committees and subcommittees", en RIESELBACH, L. N.: Legis/ative reform. Lexington, Mass., Lexington Books, 1978, págs. 35-47.

Stefanı, W.: «Das "Rules Committee" des amerikanischen Repräsentantenhauses", Politische Vierteljahresschrift, 8 (1967) n. ${ }^{\circ}$ 4, págs. 584-607.

SteIneR, Gilbert Y.: The Congressional conference committees: 70th to 80th Congresses. Urbana, University of Illinois, Press, 1951.

StEPWENS, $H$. W.: «The role of the legislative committees in the appropriation process: a study focused on the Armed Services Commitees", Western political quarterly, 24 (1971), n. ${ }^{\circ} 1$, págs. 146-162.

SWANSON, Wayne R.: «Committee assignments and the non-conformist legislator: Democrats in the US Senate», en Hirsch \& Hancock: Comparative legislative systems. New York, Free Press, 1971, págs. 279-287.

Trecker, Audrey R., y Rarleigh, B.: Committee Common Sense. New York 1954. 
UNEKIS, Joseph K.: “Congressional reform and committee decision-making", Congressional studies, 7 (1980), n. ${ }^{\circ}$, págs. 53-62.

-: «From committee to the floor: consistency in congressional voting «, Journal of politics, 40 (1978), n. ${ }^{\circ} 3$, págs. 761-770.

- : Congressional Committee politics. Continuity and change, New York. Praeger, 1984.

United States of America. Congress: History and powers of the House Committee on Rules. Washington 1963.

USLANER: Congressional Committee Assignments: Alternative Models for Behavior. Beverly Hills, 1974.

VAN DER Sulk, Jack R., \& Thomas C. Stenger: "Citizen witnesses before congressional committees", Political Science Quarterly, 92 (1977), n. ${ }^{\circ} 3$, págs. 465-485.

VINYARD, D.: «The congressional committees on small business", Western Political Quarterly, 21 (1968), n. ${ }^{\circ}$ 3, págs. 391-399.

VOGLER, David J.: «Patterns of one House dominance in Congressional Conference Committees», Midwestern Journal of Political Science, 14 (1970), págs. 303-320.

-: "Ad hoc committees in the House of Representatives and purposive models of legislative behavior», Polity, 14 (1981), n. ${ }^{\circ}$, págs. 89-109.

-: "The Third House. Conference Committees in the United States Congress. Evanston, Northwestern University Press, 1971.

WEINGANT, Barry R.: «Floor Behavior in the U.S. Congress: Committee Power under the Open Rule», en American Political Science Review, vol. 83, n. ${ }^{\circ} 3$, Washingtón, págs. $795-816$.

Westefielo, Louis P.: «Leadership and the committee system", en Peabody, R. L., \& N. W. POLSBY: New perspectives on the House of Representatives. Chicago, Rand McNally College Publishing Company, 1977, páginas 273-294.

-: «Majority party leadership and the House of Representatives", en American Political Science Review, 68 (1974), n. ${ }^{\circ}$, págs. 1593-1604.

WHITE, George: «I poteri della Commissione senatoriale affari esteri degli Stati

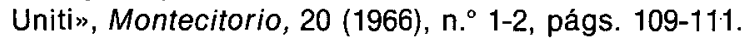


WOLANIN, Thomas R.: "Committee seniority and the choice of House subcommittee chairman», Journal of politics, 36 (1974), págs. 687-702.

ZWIRN, J.: «Congressional committee hearings», en Government publications review», 7 A (1980), págs. 453-461.

-: «Congressional committee reports", en Government publications review, 7 A (1980), págs. 319-327.

\section{c) Gran Bretaña}

Respecto al sistema parlamentario británico es común aceptar el papel secundario de las comisiones comparándolo con su significado en el Congreso americano ${ }^{18}$ a pesar de que aquéllas sean anteriores en el tiempo. En efecto, aunque es probable que existiesen comisiones en la Cámara de los Comunes desde el siglo XIV sólo se dispone de datos precisos sobre su funcionamiento a partir del siglo $\mathrm{XVI}{ }^{19}$.

El tratamiento de las comisiones británicas no puede ser unitario toda vez que hay que distinguir los Committees of the Whole House, Standing Committees y Select Committees. La Comisión de toda la Cámara tiene su justificación en la voluntad de librarse a principios del siglo Xvill del control ejercido por el Rey sobre las comisiones, principalmente por medio del Privy Council. Los Standing Committees (comisiones permanentes) nacen a raíz de la aprobación en 1882 de la propuesta planteada en 1878 por Sir Thomas Erskine May pidiendo que se crearan «comisiones de una dimensión considerable que comprendieran diputados nombrados a título personal, competentes para representar la opinión general de la Cámara, ayudados, sin embargo, por otros diputados especialmente elegidos para el estudio de proyectos particulares" ${ }^{20}$. En la actualidad llevan a cabo deliberaciones sobre los proyectos de ley pero atendiendo a las líneas básicas que les han sido fijadas por el Pleno. Los Select Committees (comisiones especiales) eran la práctica habitual en los inicios del Parlamento británico, mediatizada por la posterior aparición de los Committees of the Whole House y con la potenciación, a partir de 1907, de los Standing Committees. Se ocupan del examen de cuestiones concretas.

18 Vid. Burdeau, Georges: Traité de science politique, t. VI, vol. II, Paris 1971, págs. 356-357.

19 Mackenzie, K.: The English Parliament. Penguin books, Middlesex, 1959, págs. 59 y ss.

${ }_{20}$ Sir Thomas Enskine MaY: Treatise on the Law, Privileges, Proceedings and Usage of Parliaments, 16. ${ }^{a}$ ed., Butterworth, London 1957, pág. 141. 
The new select committees: a study of the 1979 reforms. Edited by Gavin Drewry, Oxford, Clarendon Press, 1985. Idem, 2nd. ed., 1989.

Commons Select committees: catalysts for progress?: understanding the new departmental select committees, 1979-83, editor Dermont Englesfield, Essex, Longman, 1904.

“Impartial Choices Selecting the Select committe», en The Parlamentarian, vol LXX, n. ${ }^{\circ} 2,1989$, págs. 77-82.

AlLen, F. G.: «House of Commons Expenditure Committee. La Comission des dépenses publiques de la Chambre des Communes", Constitutional and parliamentary information//nformations constitutionnelles et parlementaires, 1974, n. $^{\circ}$ 99, págs. 96-108/100-114.

Anderson, Ian G., ed.: Concils, Committees and Boards: A Handbook of Advisory in British Publis Life. Beckenham, CBD Research, 1977.

Arora, R. S.: «Parliamentary scrutiny: the select committee device», Public Law, 1967, págs. 30-41.

BARLAS, R. D.: «Protection of select committees sitting outside the Palace of Westminster», The Table, 38 (1969), págs. 80-84.

BeamisiH, D. R.: "The House of Lords Select Committee on Practice and Procedure, 1976-1979", The Table, 47 (1979), págs. 37-47.

BENNETT, Anthea: "Advising the Cabinet: the Committee of Civil Research and the Economic Advisory Council: A Brief Comparison», Public Administration, 56 (Spring 1978), págs. 51-71.

Bentley, Phyllis: Committees, London 1962.

BoDY, Richard: "Unofficial Committees in the House of Commons", en Parliamentary Affairs, 11 (Summer 1958), págs. 295-302.

Borthwick, R. L.: «Up-dating on Parliament: Recent changes in House of Commons committees», en Teaching politics, 9 (1980), n. ${ }^{\circ} 3$, págs. 228-241.

-: "When the Short Cut May be a Blind Alley: The Standing Committee on Regional Affairs", Parliamentary Affairs, 31 (Spring 1978), págs. 201209.

-: "An Early Experiment with Standing Committees in the House of Lords", Parliamentary Affairs, 25 (Winter 1971/1972), págs. 80-86. 
BoRTHWICK, R. L.: «Public Bill Committees in the House of Lords», en Parliamentary Affairs, 26 (Autumn 1973), págs. 440-453.

-: "The Welsh Grand Committee», Parliamentary Affairs, 21 (Summer 1968), págs. 264-276.

BоттомLEY, Arthur: «Specialized Select Committee Procedure in U.K.», Journal of Parliamentary Information, 22 (1976), págs. 215-219.

Boulton, C. J.: «Le commissioni della Camera dei Communi», en Bolletino di informazioni costituzionali e parlamentari, 18 (1967), n. ${ }^{\circ}$, págs. 69-75.

-: "Committees in the British House of Commons", en Constitutional and Parliamentary Information, 68 (1966), págs. 192-196.

Boys-CARPENTER, John: «Development of the Select Committee in the British Parliament», Parliamentarian, 52 (April 1971), págs. 101-104.

BranCH, John L.: Committee Practice and Procedure, 1899.

BRookE, John: General Index to Reports from Committees of the House of Commons 1715-1801. Bishops Short Ford, Chadwyckhealy, págs. 1973.

Burns, J. H.: «Scottish Committees of the House of Commons, 1948-59", en Political Studies, 8, octubre de 1960, págs. 272-296.

BYrNe, Paul: «The Expenditure Committee: a preliminary assessment», Parliamentary Affairs, 27 (1974), n. ${ }^{\circ}$ 3, págs. 273-286.

Chapman, Donald: "The Select Committee on Procedure at Westminster", en The Parliamentarian, 51 (1970), n. ${ }^{\circ}$ 2, págs. 139-144.

CHIEN, Thomson S.: «Parliamentary Committees: A Study in Comparative Government», Ph. D. dissertation, Harvard University, 1924.

Chowdharay-Best, George: "The history of standing committee", en The Parliamentarian, 57 (1976), n. ${ }^{\circ}$, págs. 289-293.

Chuвв, Basil: The control of public expenditure: financial committee of the House of Commons. Oxford, Clarendon Press, 1957.

-: “The Select Committee on Estimates, 1946-48», en Parliamentary affairs, 2 (1949), n. ${ }^{\circ} 3$, págs. 284-291.

CoOmbes, David: The Member of Parliament and the Administration. The case of the Select Committee on Nationalized Industries. London, Allen \& Unwin, 1966. 
COOMBES, DAVID: “The scrutiny of Ministers' powers by the Select Committee on Nationalized Industries», en Public Law, 1965, págs. 9-29.

CoOmbes, David L.: The Member of Parliament and the Administration: The Case of the Select Committee on Nationalized Industries, London, Allen \& Unwin, 1966, pág. 221.

-: “The Scrutiny of Ministers' Powers by the Select Committee on Nationalized Industries», en Public Law, Spring 1965, págs. 9-29.

«Сомmittee structures»: The Table, 49 (1981), págs. 92-124 (págs. 92-95, United Kingdom).

D'Avignor-Goldsmid, Sir Henry: "The House of Commons Expenditure Committee", en The Parliamentarian, 54 (1973), n. ${ }^{\circ}$ 4, págs. 205-208.

Davies, E.: «Select Committee on Nationalized Industries", en Political Quarterly, 29, october 1958, págs. 378-388.

DeLPECH, Joseph: «Notes sur les commissions et comités permanents. A propos des nouveaux Standign Orders 46-48 de la Chambre des Communes (16 Avril 1907)", en Revue Française de Droit Public et de la Science Politique, 1908.

DomINICl, D.: Le commissioni parlamentari inglesi. Milano, Giuffrè, 1970, páginas 308.

Downs, Stephen: «The House of Commons: structural changes: select committes", en Parliament in the 1980. Edited by Philip Norton, Oxford, Basil Blackwell, 1985, págs. 48-67.

DrewrY, Gavin: «Select committees and backbench power», en The changin constitution. Edited by Jeffrey Jowell and Dawn Oliver, Oxford, Clarendon Press, 1985, págs. 127-148.

Edwards, G. E.: «The Scottish Grand Committee, 1958 to 1970", en Parliamentary Affairs, 25 (Autumn 1972), págs. 303-325.

EDWARDS, John Goronwy: «Parliamentary Committee of 1398", en English Historical Review, 40 (July 1925), págs. 321-333.

EuLAU, Heinz: “Committee selection”, en Handbood of legislative research. London, Harvard University Press, 1985, págs. 191-237.

Farmer, H. R. M.: «The Select Committee on Procedure», en The Table, 32 (963), págs. 35-38. 
Flegmann, Vilma: Called to account. The Public Accounts Committee of the House of Commons, 1965-66/1977-78. Westmead, Gower Publishing Company, 1980, 318 págs..

-: «The Public Accounts Committee: A successful select committee?», Parliamentary Affairs, 33 (1980), n. ${ }^{\circ}$ 2, págs. 166-172.

Gilmour, Kay: Committee Procedure. London 1950.

Gladden, E. N.: “The Estimates Committee looks at the civil service», en Parliamentary Affairs, 19 (1966), n. ${ }^{\circ}$ 2, págs. 233-240.

GLow, Lotte: “Committee of Safety», en English Historical Review, 80, (April 1965), págs. $289-313$.

Goldsworthy, David: «The Debate on a Parliamentary Committee for Colonial Affairs", en Parliamentary Affairs, 19, (Spring 1966), págs. 191-207 y 252.

Grantham, Cliff: «The House of Lords: Structural changes: the use of committees", en Parliament in the 1980s. Edited by Philip Norton, Oxford, Basil Blackwell, 1985, págs. 114-135.

GREY, J. E.: «Delegated legislation in the United Kingdom Parliament- the work of the Brooke Committee, 1971/72, 1972/73", en The Table, 42 (1974), págs. 47-60.

GRIFFITH, John A. G.: «Special Report from the Select Committee on the House of Commons Disqualification Bill (H. C. 349 of 1955-1956)", en Modern Law Review, 20 (January 1957), págs. 52-54.

-: "Standing committees in the House of Commons", en WALKLAND, S. A., \& M. RyLE: The Commons of the seventies. Glasgow, Collins, 1977, páginas 95-112.

-: "Standing committees in the House of Commons", en WALKLAND, S. A., \& M. RYLE: The Commons today. Isle of Man, Fontana Books, 1981, páginas 118-136.

HAMM, Keith E.: “Legislature committees, executive agencies and interest groups", en Hadbook of legislative research. London, Harvard University Press, 1985, págs. 573-620.

—: “Standing committees in legislatures», en ibidem, págs. 395-470.

Hanson, Albert Henry: «Parliamentary Control of Nationalized Industries», Parliamentary Affairs, 11 (Summer 1958), págs. 328-340. 
HANSON, Albert Henry, and WISEMAN, Herbert V.: "The Use of Committees by the House of Commons", Public Law, 1959 (Autumn 1959), páginas 277-292.

Herbert, Alan P.: Anything But Action? A Study of the Uses and Abuses of Committees of Inquiry. London, Barrie and Rockcliff, 1960, 52 páginas.

HimelfarB, Sheldon: «Consensus In committee: The case of the Select Committee on Race Relations and Immigration", Parliamentary Affairs, 33 (1980), n. ${ }^{\circ}$, págs. 54-66.

HIGgins, Graham M.: The Origin and Development of the Standing Committees of the House of Commons, with Special Reference to Their Procedure, 1882-1951. D. Phil., Oxford University, 1953.

Hughes, Christopher J.: «The Early History of Standing Committees, 18321905», Parliamentary Affairs, 2 (Autumn 1949), págs. 378-390.

HyoER, Massod: «Parliament and defence affairs. The Defence Sub-Committee of the Expenditure Committee", en Public Administration. London, 55 (1977), págs. 59-78.

IwI, Edward F.: «Select Committee», Modern Law Review, 8 (November 1945), págs. $240-243$.

JoHNSON, Nevil: "Select committees and administratio", en WALKLAND, S. A.: The House of Commons in the Twentieth Century. Oxford, Clarendon Press, 1979, págs. 426-475.

-: "Select committees as tools of parliamentary reform: some further reflections", en WALKLAND, S. A., \& M. RYLE: The Commons in the seventies. Glasgow, Collins, 1977, págs. 175-201.

-: Parliament and administration. The Equipment Committee 1945-65. London, Allen \& Unwin, 1966.

JONES, J. Barry: Parliament and Territoriality: the committee on welsh affairs 1979-1983. Cariliff, University of Wales Press, 1986.

KENNON, Andrew: «Recent work of the General Sub-Committee of the Expenditure Committee", en Parliamentary Affairs, 33 (1980), núm. 2, páginas $159-165$.

KeRshaw, Sir Anthony: The Canadian Constitution and the Foreign Affairs Committee of the U. K. House of Commons, 1980 and 1981», The Parliamentarian, 62 (1981), n. ${ }^{\circ} 3$, págs. 173-182. 
KIMBER, Richard H., and RICHARDSON J. J.: «Specialization and Parliamentary Standing Committees", Political Studies, 16 (February 1968), páginas 97-101.

KoEster, C. B.: «Standing Committees in the British House of Commons", Parliamentariam, 49 (April 1968), págs. 64-72.

LANKESTER, R. S.: «House of Commons select committees related to Government Departments», en The Table, 48 (1980), págs. 29-34.

-: "Specialist Committees in the House of Commons", en The Table, 38 (1969), págs. 64-79.

LEE, J. M.: "Select Committees and the Constitution", Political Quartely, 21 (April 1970), págs. 182-194.

LEES, J. D., ed.: Committees in legislatures: A comparative Analysis. London 1980.

LINSTEAD, Hugh: «The Parliamentary and Scientific Committee», en Parliamentary Affairs, 9 (Autumn 1956), págs. 465-469.

MCCONVILLE, Sean: «Committees of Inquiry and penal policy in England», Statsvetenskapelig tidskrift, 1981, núm. 1, págs. 21-28.

Mac Leay, Leo: «Off whit his head. Protection for House Committee witnesses, en The Parliamentarian, 1966 (I), págs. 9-13.

MAC NeISH, Thea: «Select Committees at the House of Commons", en Contemporany Review, London 1987, págs. 89-95.

MACKINTOSH, John P.: Specialist Committees in the House of Commons: Have They Failed? Edinburgh, Departament of Politics, University of Edinburgh, 1971.

MARSH, lan: «Interest groups and Policy making: A new role for select committees?», en Parliamentary Affairs (4), 1988, págs. 469-489.

—: Policy making in a three party system: committees, coalitions and Parliament. London, Methuen, 1986.

MAtheR, Jean: «The Parliamentary Committees and the Justices of the Peace, 1642-1661", American Journal of Legal History, 23 (April 1979), páginas $120-143$. 
MILLER, Harris N.: "The Influence of British Parliamentary Committees on European Communities Legislation", Legislative Studies Quarterly, 2 (February 1977), págs. $45-75$.

Mitchell, Austin: «Inside the Commons Treasury Committee: the Report on the Civil Service», en Parliamentary Affairs, n. ${ }^{\circ}$ 5, 1987, págs. 468-481.

Morgan, G.: “All Party Committees in the House of Commons", en Parliamentary Affairs, 32 (Spring 1979), págs. 56-65.

MorRIs, Alfred, ed.: The Growth of Parliamentary Scrutiny by Committee: $A$ Symposium. Oxford, Pergamon Press, 1970.

MUKHERJEe, B. K.: "Committee on the absence of Members from the sitting of the House», Journal of parliamentary information, 22 (1976), núm. 4, págs. 639-660.

MYERS, P.: «The Select Commitee on Scottish Affairs", en Parliamentary Affairs, 27 (Autumn 1974), págs. 359-370.

-: "A New Report from the Nationalized Industries Committee", en Parliamentary Affairs, 13 (Winter 1959-1960), págs. 95-99.

Neave, Airey: Control by Committee: The Reform of the Committee System of the House of Commons. London, Conservative Political Center, 1968.

Norton, Philip: «Dissent in Committee: Intra-Party Dissent in Commons' Standing Committees, 1959-74», Parliamentarian, 57 (January 1976), páginas 15-25.

- :Standing Committees and the Composition of the House», Parliamentarian, 57 (October 1976), págs. 293-295.

PALMER, Arthur: "The Select Committee on Science and Technology", Parliamentarian, 50 (April 1969), págs. 102-105.

PARtington, Martin: «Parliamentary Committees: Recent Developments», Parliamentary Affairs, 23 (Autumn 1970), págs. 366-379.

PoHL, Alice N.: Boards and committees: a handbook on parliamentary procedures. Parlie Publications, 1984.

Poole, K. P.: «The Powers of Select Committees of the House of Commons to Send for Persons, Papers and Records", Parliamentary Affairs, 32 (Summer 1979), págs. 268-278. 
Popham, G. T., and Greengrass, D.: "The Role and Functions of the Select Committee on Agriculture», Public Administration, 48 (Summer 1970), págs. 137-151.

Powell, Christopher, \& Arthur ButLer: The Parliamentary and Scientific Committee. The first forty years 1939-1979. London, Helm, 1980.

PrING, David: “Standing Committees in the House of Commons", en Parliamentary Affairs, 11 (June 1958), págs. 303-317.

Proctor, W. A.: «The House of Commons Select Committee on Procedure, 1970-1979», The Table, 47 (1979), págs. 13-36.

RYLE, Michael: "Committees of the House of Commons", Political Quarterly, 36 (July 1965), págs. 295-308.

-: «Overseas travel by select committees of the United Kingdom Parliament», The Table, 47 (1979), págs. 124-127.

SAINTY, J. C.: "The Joint Committee on House of Lords reform and the Peerage Bill», The Table, 31 (1962), págs. 13-25.

ScotT, D.: "The Financial Bill of 1968 in Standing Committee», The Table, 37 (1968), págs. $75-80$.

-: "The Select Committee on the Civil List (Sessions 1970-71 and 1971-72)", The Table, 40 (1971), págs. 84-89.

«Select Committees of the House of Commons, Westminster», en Parliamentarian, 52 (January 1971), págs. 78-82.

ShackLeton, Lord: «The Parliamentary and Scientific Committee", en Parliamentarian, 60 (July 1979), págs. 149-151.

Shakdher, S. L.: Two estimates Committees (U. K. and India). New Delhi, Government of India Press, 1959.

SheARer, J. G. S.: "Standing Committees in the House of Commons", en Parliamentary Affairs, 3 (Autumn 1950), págs. 558-568.

SHelL, Donald R.: “Specialist Select Committees», Parliamentary Affairs, 23 (Autumn 1970), págs. 380-404.

SILKIN, S. C.: "The Select Committee on Parliamentary Privilege in the U. K.», The Parliamentarian, 51 (1970), n..$^{\circ}$, págs. 1-10. 
Simmons, R. H.: «Role of the Select Committee on Nationalized Industry in Parliament», Wester Political Quarterly, 14 (September 1961), páginas 741-747.

Strauss, George: “The Member's Financial Interests: Select Committee at Westminster», Parliamentarian, 51 (April 1970), págs. 96-100.

Study of Parliament Group: Specialist Committees in the British Parliament: The Experience of a Decade. London, PEP, 1976.

TAYLOR, Eric S.: «The Select Committee on Parliamentary Privilege, 1966-67", The Tab/e, 37 (1968), págs. 16-25.

UNITED KINGDOM: House of Lords. Select Committee on Practice and Procedure. First report. London 1977.

-: House of Lords \& House of Commons. Joint Committee on Sound Broadcasting. Second report. London 1977.

—: “Watchdog committees» en The Parliamentarian, 60 (1979), n. ${ }^{\circ}$, páginas $248-249$.

WALKLAND. S. A.: "Das neue Ausschussystem des britischen Unterhauses", Zeltschrift für Parlamentsfragen, 12 (1981), n. ${ }^{\circ}$, págs. 463-473.

-: "Science and Parliament: the Origins and Influence of the Parliamentary and Scientific Committee", Parliamentary Affairs, 17 (Summer 1964), págs. 308-320; 17 (Autumn 1964), págs. 389-402.

-: "Science and Parliament: The Role of the Select Committees of the House of Commons", Parliamentary Affairs, 18 (Summer 1965), págs. 266-278.

-: «Unusual or Unexpected Use and the Select Committee on Statutory Instruments», Parliamentary Affairs, 13 (Winter 1959/1960), págs. 61-69.

-: "Committees in the British House of Commons", en Committees in Legislatures: A Comparative Analysis. Edited by John D. Lees and Malcolm Shaw, págs. 242-287. Durham, N. C., Duke University Press, 1979.

Westminster: “Committee of Privileges First Report», en The Parliamentarian, 58 (1977), n. ${ }^{\circ} 2$, págs. 134-135.

WHEARE, K. C.: Government by committe: an essay on British Constitution. Clarendon Press, Oxford, 1968.

WILCox J. H.: "Some Aspects of the Early History of Committees of the Whole House», Parliamentary Affair, 7 (Autumn 1954), págs. 409-419. 
WiLliams, Roger: «The Select Committee on Science and Technology: The First Round», Public Administration, 46 (Autumn 1968), págs. 299-313.

Wiseman, Herbert V.: «Procedure: the House of Commons and the Select Committee», Parliamentary Affairs, 13 (Spring 1960), págs. 236-247.

ZebeL, S. H.: "The Committee of the Whole in the Reign of James |», American Political Science Review, 35 (October 1941), págs. 941-952.

\section{d) Francia}

Desde 1789 la Asamblea Nacional organizó comisiones permanentes, potenciadas considerablemente durante el período de la Convención hasta el punto de que, según EUGÉNE PIERRE, «de 1792 a 1795 los comités fueron los verdaderos depositarios del poder ejecutivo» ${ }^{21}$. Prohibidos posteriormente por la Constitución del Directorio del año III, aparecieron en 1807 como Comisiones Permanentes Legislativas hasta el Reglamento de 1814 que vuelve al sistema de Comisiones especiales. Las reformas reglamentarias de noviembre de 1902 instauran las Comisiones permanentes, confirmadas durante la $V$ República, aunque el artículo 43.2 de la Constitución de 1958 limite a seis las de cada Cámara. Su labor ha quedado limitada a funciones técnicas de preparación del trabajo posterior del Pleno. Existen también Comisiones de investigación y Comisiones paritarias mixtas de las dos Cámaras.

Les Commissions parlementaires, La documentation française, Paris 1968.

Les Commissions à l'Assemblée nationale, Economica, Paris 1990.

«Pour connaître le Senat», La documentation française, 1975 (págs. 87-95: les commissions; págs. 159-164: l'examen en commissions; págs. 218-220: commissions d'enquête et de contrôle).

L'accés du public aux réunions des commissions", en Informations Constitutionnelles et Parlementaires, $n .^{\circ} 125-126,1981$.

"Le système des commissions parlementaires", en Informations Constitutionnells et Parlementaires, 3 y 4 trimestres, 1984.

${ }^{21}$ Pierre, Eugène: Traité de Droit politique, électoral et parlementaire, 4. ${ }^{\text {a }}$ ed. (supplément 5. ${ }^{\circ}$ ed. 1924), pág. 737. 
BARTHELLEMY, Josep: Essai sur le travail parlementaire et le système des commissions, Librairie Delagrave, Paris 1934.

BonNARD, M.: “Les commissions spéciales à l'Assemblée Nationale 19591979", en Revue Française de Sciences Politiques, 1981.

BRETON: Les Commissions et la procedure parlementaire. Paris 1922.

Byays, Philippe: «Les commissions d'enquête parlementaire», en Revue du Droit Publique et de la Science Politique, n. ${ }^{\circ} 2,1954$, págs. 443-486.

Cahoua, Paul: «Les commissions, lieu du travail», en Pouvoirs, n. ${ }^{\circ} 34,1985$, págs. 37-40.

CoustIS DE LA RIVIĖRE, Gérard: Les commissions parlementaires d'enquête et la séparation des pouvoirs, Rennes, Université, 1926.

Cuevas y Cuevas, Miguel: "Las Comisiones permanentes en los Parlamentos de Francia y España», en Revista General de Legislación y Jurisprudencia, tomo 147, 1925, págs. 333-412.

DENIAU, Xavier: "La francophonie en commissions d'enquête", en Revue politique et parlementaire, $\mathrm{n}^{\circ} 890,1981$, págs. 69-76.

DESANDRE, Jacques: «Les Commissions parlementaires d'enquête ou de control en droit trançais", en La documentation française. Paris 1976.

-: "Les commissions d'enquête ou de control: secret ou publicité des travaux», en Pouvoirs, n. ${ }^{\circ} 34,1985$, págs. 51-66.

-: «La responsabilité des personnes entendues par les commissions parlementaires d'enquête", en Revue du Droit Public et de la Science Politique en France et a l'Etranger. Paris 1986 (3), págs. 731-740.

Fournol, E.: «The system of parliamentary commissions in France», en The New Europe, Aug., 1. ${ }^{\circ}, 1918$.

Gascón y MARín: «Le rôle des Commissions parlementaires", en Annuaire de l'Institut International de Droit Public, 1932, págs. 184 y ss.

GeORgE, Henri: «Les pouvoirs de rapporteurs des commissions parlementaires", en Mélanges offerts à Georges Burdeau: Le pouvoir, Paris, LGDJ 1977, págs. 441-453.

Hamon, L., et CotTeret, J. M.: «Le rôle de la commission mixte paritaire», en Revue du Droit Publique, 1960. 
Harrison, M.: «The composition of the committees in the French National Assembly", en Parliamentary Affairs, ${ }^{\circ}{ }^{2}$ 2, 1958, págs. 172-179.

LAVRofF, Dimitri: "Les commissions de l'Assemblés Nationale sous la V. ${ }^{a}$ République», en Revue du Droit Publique, n. ${ }^{\circ}$ 6, 1971.

LEgRES, A.: “Les commissions parlementaires d'enquête et de contrôle», en Après-demain, n. ${ }^{\circ} 150,1973$, págs. 25-26.

Le Morzellec, Joëlle: "Sur quelques innovations récents en matière budgétaire-réunions ouvertes et commissions élargies", en Annales de l'Université Jean Moulin. Série UER, Faculté de Droit, n. ${ }^{\circ} 2,1977$, págs. 3165.

LINDSAY, Rogers: «Parliamentary Commissions in France», en Political Science Quarterly, vol. 38, 1923.

LouIs-LucAs, P.: «Les pouvoirs propres des commissions des finances», en Revue de Droit Public, n. ${ }^{\circ} 70,1954$, págs. $722-752$.

LOQUET, Patrick: «Les Commissions parlementaires permanents de la V République", en Travaux et Recherches de la Université de Lille, II, PUF, 1980.

PACTET, Pierre: «Les commissions parlementaires", en Revue du Droit Public, n. ${ }^{\circ} 1,1954$, págs. 124-172.

SCHELLKNECHT, Helmut: "Le système des commissions parlementaires», en Informations Constitutionnelles et Parlementaires, n. ${ }^{\circ} 139-140,1984$, págs. 93-197.

THERON, J. P.: «L'intervention de la Commission mixte paritaire dans l'élaboration des lois de finances", en Ann. Toulouse, tomo XXVII, 1979.

Trnka, H.: “La Commission mixte paritaire», en Revue du Droit Public, 1963, págs. 403 y ss.

VILLARD, Pierre: «Les comités permanentes de l'Assemblée Nationale Constituante française, mai 1848", en Parliaments, Estates and Representation, London 1985 (2), págs. 139-164.

e) Alemania

La existencia de las comisiones ha sido una constante en el ordenamiento jurídico alemán ${ }^{22}$. En la actualidad, según la Ley Fundamental

22 Véase Villacorta Mancebo, Luis, op. cit., págs. 125-127. 
de Bonn, el Bundestag Federal y los Parlamentos de los Länder recogen, asimismo, esta figura con una importancia destacada en el complejo procedimiento legislativo alemán de las tres lecturas hasta el punto de que para DENNINGER «el núcleo esencial del procedimiento legislativo reside en la práctica en el trabajo de las Comisiones" ${ }^{23}$.

Amank, $\mathrm{H}$.: «Verfassungsechtliche Probleme des Gemeintemen Ausschusses nach Art. 53a ABs, 1 GG.», en Frankfurt Main, Athenëum, 1971.

SeCKeR, W. P.: “Das Recht parlamentarischer Untersuchungssusschüsse», en Zeitschrift für Parlamentsfragen, 1972, n. 4, págs. 425-462.

Bemandlung nicht-überwiesener Angelegenheiten in den Parlamentsausschüssen des Bundes und der Länder (Stand April 1973) (1974), en Zeitschift für Parlamentsfragen, $\mathrm{n} .^{\circ} 1$, págs. 14-16.

BERG, W.: «Zur Ubertragung von Aufgaben des Bundestages auf Auschüsse», en Der Staut, n. ${ }^{\circ} 1,1970$, págs. 21-42.

BODENHEIM, D. G.: Kollision parlamentarischer Kontrollrechte. Zum verfassungsrechtlichen Verhältnis von parlamentarischem Frage-und Untersuchungsrecht (1979).

Вонм, F.: «Der Arbeitsstil des Bundestages. Gedanken und Anregungen zur Tätigkeit der Ausschüsse” (1964), en Die Neue Gese//schaft, n. ${ }^{\circ} 5$, páginas 347-353.

Elvira Perales, Ascensión: “Comisiones de investigación en el "Bundestag". Un estudio de jurisprudencia", en Revista Española de Derecho Constitucional, n. ${ }^{\circ} 19$, págs. 263-282.

(Germany, Federal Republic of). Deutscher Bundestag. Wissenschaftliche Dienste. Die Ausschüsse des Deutschen Bundestages. 9. Wahlperiode. Stand: 1. September 1981. Bonn 1981.

HASSELSWEILER, Ekkehart: «Der Vermittlungsausschuss. Verfassungsgrundlagen und Staatspraxis. Eine Untersuchung der parlamentsrechtlichen und Verfassungspolitischen Bedeutung des Ausschusses nach Art. 77

23 Denninger, Erhard: «El procedimiento legislativo en la República Federal de Alemania", en Revista Española de Derecho Constitucional, n. ${ }^{\circ} 16,1986$, página 40. 
Abs. 2 des Grundgesetzes unter besonderer Berücksichtigung seiner Verfahrenspraxis. Berlin, Duncker \& Humblot, 1981.

Hoffmann-RIEm, Wolfgan; Ramcke, Udo: «Enquete-Kommissionen», en Parlamentsrecht und Parlamentspraxis in der Bundesrepublik Deutschland. Ein Handbuch herausgegeben von Hans Peter Schneider und Wolfgang Zeh, Berlin, XVIII, 1989, pp. 1261-1292.

KEWENING, W.: Staatsrechtliche Probleme parlamentarischer Mitregierung am Beispiel der Arbeit der Bundestagsausschüsse (1970), Bad Humberg, Gehlem.

KLEIN, H. H.: Zur Rechtsstellung des Bundestagsabgeordneten als Ausschussmitglied (1972), en Offentliche Verwaltung, n. ${ }^{\circ} 10$, págs. 329-331.

LOMPE, Klaus; Hans Heinrich RAsS \& Dieter REHFELD: “Enquête-Kommission und Royal Commissions. Beispiele wissenschaftlicher Politikberatung in der Bundesrepublik Deutschland und in Grossbritannien». Mit einem Beitrag zur Paritätischen Kommission in Osterreich. Göttingen, Vandenhoeck \& Ruprecht, 1981, 374 pág. (págs. 181-290: Bundesrepublik Deutschland).

SCHADFER, F.: «Der Untersuchungsausschuss (1): Kampfstätte oder Gericht?» (1974), en Zeitschrift für Parlamentsfragen, n. ${ }^{\circ}$, págs. 446-502.

SCHMITINER, K.: «Die Enquete - Kommissionen des Deutschen Bundestages (1972)", en Zeitschrift für Parlamentsfragen, n. ${ }^{2}$ 2, págs. 209-229.

ScHOLz, Rupert: «Parlamentarischer Untersuchungsausschuss und Steuergeheimnis", en Archiv des öffentlichen Rechts, 105 (1980), n. 4 , páginas $564-622$.

ScHWEITZER, C. C.: «Der Ausswärtige Ausschuss des Deutschen Bundestages im aussen politischen Entscheidungssystem", en Aus Politik und Zeitgeschichte, 1980, n. ${ }^{\circ} 19$, págs. 3-24.

StefFanI, W. Der L.: «Untersuchungsausschuss des VII. Deutschen Bundestages: zum Erfahrungsbericht des "Steiner-Ausschusses"» (1974), en Zeitschrift für Parlamentsfragen, $n .^{\circ} 4$, págs. 470-472.

StefFan, W.: «Funktion und Kompetenz parlamentarischer Untersuchungsausschüsse (1960)", en Politische Vierteljahreschrift, n. ${ }^{\circ}$ 2, páginas 153-177.

TAYloR, R. W., \& M. von NordheIM: "Petitions committees and Crievance Resolution in the FRG" (1973), en Midwest review of public administration, n. ${ }^{\circ} 4$, págs. $215-228$. 


\section{f) Italia}

El origen de las Comisiones permanentes en el Parlamento italiano se encuentra en el nacimiento de los grupos parlamentarios durante la experiencia prefascista, apreciándose la necesidad de crear un procedimiento de examen previo de las leyes respetando la representación proporcional de esos grupos nacidos en aquel momento ${ }^{24}$. Aparecen de este modo en 1920 las Comisiones permanentes por materias, que en el actual sistema son, junto con la Oficina de la Presidencia, «el órgano básico que asegura la continuidad de las tareas del Parlamento y su diálogo con el Gobierno, labor esta última facilitada por la misma tendencial especialización de las distintas comisiones en las materias que son competencia de cada ministerio" ${ }^{25}$.

La importancia de estas Comisiones permanentes se constitucionaliza en el artículo 72 del texto de 1947 al exigir que todos los proyectos de ley sean examinados con carácter previo por una Comisión. Es preciso mencionar también las Comisiones especiales para el estudio de un tema específico y las Comisiones de encuesta o investigación sobre materias de interés público (art. 82).

Manualle delle Commissioni bicamerale: norme e strutture. Camera dei Deputati. Roma 1984.

Parlamento e politica estera. I/ ruollo delle Commissioni Affari Esteri a cura di A. Cassese. Cedam, Padova 1982.

Francia-Italia. Sistemi istituzionali a confronto. Incontri tra la Commission des Lois dell'Assamblea Nazionale e la Commissione Affari Costituzionali della Camera dei Deputati. Versailles, novembre 1983. Roma, gennaio, 1985.

Affinita, T.: «Aspetti problemati del rapporto tra Parlamento e Pubblica Administrazione. Dall'esperienza della Commissione Lavori Pubblici del Senato», en Studi parlamentari e di politica costituzionale, $n .^{\circ}$ 52-53, 1981, págs. 133-143.

${ }^{24}$ Cfr. Longl, Vicenzo: Elementi di Diritto e procedura parlamentare, Milano, Dott. A. Giuffrè, 1978, pág. 95.

${ }_{25}$ Pizzonusso, Alessandro: Lecciones de Derecho Constitucional, II, Centro de Estudios Constitucionales, Madrid 1984, págs. 270-272. 
Baldassarre, A.: «Esperienze e prospettive delle commissioni bicamerali», en II Parlamento nella Costituzione e nella realtà. Atti, regolamenti e prassi nella VII Legislatura. Milano 1979, págs. 155 y ss.

BerARducci, Elio: «La revisioni delle competenze delle commissioni permanenti», en // Parlamento della Repubblica: organi, procedure, apparati. Roma. Camera dei Deputati, V. I, 1987, págs. 45-66.

BertolinI, G.: «Le commissioni parlamentari nei nuovi regolamenti della Camera e del Senato", en Studi parlamentari e di politica costituzionale, n. ${ }^{\circ} 21,1973$.

Bruno, Fernanda: Le commissioni parlamentari in sede politica. Milano, Dott. A. Guiffrè, 1972.

BUONPENSIERE: “Commissioni bicamerali e forma de governo vigente», en Studi parlamentari e di politica costituzionale, n. ${ }^{\circ} 47-48,1980$, págs. 41 y ss.

CARDIA, Carlo: «La programmazione dei lavori di aula e di commissione», en la ob. col. II Parlamento, analisi e proposte di reforma. Cuaderno especial n. 2 de la revista Democrazia e Diritto. Roma 1978, páginas $27-54$.

Ciaurro, G. F.: «Le commissioni bicamerali nell'esperienza parlamentare italiana", en Bollettino di informazioni costituzionale e parlamentari, 1, 1981.

CleRICI, Edoardo: "Le Commissioni legislative permanenti», en Studi per il ventesimo anniversario dell'Asamblea Costituente, vol. V. Le Camera istituti e procedura, págs. 203-220.

COSENTINO, F.: “Parliamentary committees in the Italian political system», en Journal of constitutional and parlamentary studies, $n,{ }^{\circ} 2,1967$, páginas 1-2.

Cosentino, Ubaldo: «Legislative powers of committees in the Chamber of Deputies", en Constitutional and parliamentary information, $\mathbf{n} .^{\circ} 2,1950$, págs. 94-95.

CutelLI, Guisseppe Salvatore: «La Commissione anti-mafia ter già iniziato i lavore», en Nuova Rassegna, vol. LXIII, 7-8, 1989, págs. 846-853.

Chimentı, Carlo: “Un'esperanza parlamentare nuova: la Commissione senatoriale per i problemi ecologici», en Foro, amm. 1972. 
Chimenti, Carlo: «Le'udienze conoscitive delle commissioni senatoriali», en Istituto per la documentazione e gli studi legis/ative. Indagine sulla funzionalità del Parlamento, vol. II, 1969, págs. 173-184.

-: "Appunti sulle commissioni "consultive"», en / Parlamento nella Costituzione e nella realtà. Atti, regolamenti e prassi della Camera nella VII Legislatura. Atti del Convegno del Gruppo Parlamentare Radicale. Roma 1978; Milano, Guiffrè, 1979, págs. 479-484.

ELIA, Leopoldo: «Le Commissioni parlamentari italiane nel procedimiento legislativo", en Archivo giuridico Filippo Serafini, 1961.

D'EufEMIA, Guisseppe: «Le Commissioni parlamentari nelle Costituzioni moderne", en Rivista trismestrale di Diritto Pubblico, n. ${ }^{\circ} 1,1956$.

D'Onofrio, F.: Le indagini conoscitive delle commissioni parlamentari. Problemi e prospettive. Ed. Università di Chieti, 1971.

DogLIANI: "Commissione antimafia e segreto "funzionale": i documenti li leggerano gli storici», en Giurisprudenza Costituzionale, II, 1975, páginas 3216 y ss.

FEnuccl: / limiti del/ inchiesta parlamentare. Nápoles 1968.

FranCESCH, Paolo: «Natura, istrumentazione e finalità della programmazione dei lavori parlamentari in Assemblea e in Commissione», en Bollettino di Informazioni Costituzionali e Parlamentari, 1985, n. ${ }^{\circ} 3$, páginas $108-124$.

Fraternale, R.: «l comitati paritetici nelle indagini conoscitive bicamerali», en Studi parlamentari e di politica costituzionale, n. ${ }^{\circ} 51,1981$, páginas 67-77.

Garlato, G.: «Le Commissioni permanenti del Parlamento italiano», en Studi per il XX anniversario dell'Assemblea costituente, V, Firenze, 1969.

GHELARDUCCI, F.: “Le commissioni parlamentari in sede politica", en Studi parlamentari e di politica costituzionale, $\mathrm{n} .{ }^{\circ} 21,1973$, págs. 105-125.

GoGUEL, F.: «La procédure italienne de vote des lois par les commissions», en Le travail parlementaire en France et à l'etranger, Paris, PUF, 1955, págs. 168-174.

- Idem en Revue Française de Science Politique, 1954.

LA LogGIA, E.: Le Commissioni nell'ordinamento parlamentare italiano. Palermo 1974. 
LANZILLOTTA, Lidia: «Le Commissioni di merito nella decisione finanziaria e di bilancio", en Bollettino di Informazioni Costituzionali e Parlamentari, n. ${ }^{\circ} 3,1986$, págs. $129-153$.

LETTA, Guido: "ll sistema delle Commissioni permanenti dopo le recenti riforme regolamentari della IX e della X Regislatura. In particolari: le modifiche alla sede legislativa e alle competenze. Profili applicativi e organizzativi", en II Parlamento della Repubblica. Organi, procedure, apparati. Camera dei Deputati, Roma 1990. V. III: 1988-1989, IX, páginas $1-26$.

Longl, Vincenzo: Le Commissioni parlamentari e la Costituzione. Milano, A. Giuffrè, 1953.

LongI-STRAMACCI: «Le Commissioni parlamentari e la Costituzione», en Quarderni della Costituzione. Milano 1953, págs. 19 y ss.

MANzeLLA, Andrea: «Procedimiento legislativo in commissione redigento", en II Parlamento. II Mulino, 1977, págs. 330 y ss.

Mariuzzo, P.: «Leggi accordo e comitati ristretti», en Studi parlamentari e di politica costituzionale, $\mathrm{n} .{ }^{\circ} 38,1977$, págs. $80-82$.

MARRA, D.: «Prospettive di riforma del procedimento legislativo in commissione redigente», en Studi parlamentari e di politica costituzionale, n. ${ }^{\circ} 51,1981$, págs. 51-66.

MICHELI: “Inchiesta parlamentare», en Enciclopedia Giuridica italiana, vol. VIII, Milán 1902.

NocilLA, D.: «Presidenza delle commissioni e maggioranza parlamentares», en Diritto e Società, 1973.

-: «ll difficile avvio del funzionamento delle Commissione antimafia nella VI legislatura», en Diritto e Società, 1973.

PACE, A.: «Commissione parlamentare antimafia e giudice penale (una cronaca costituzionale)", en Diritto e società, 1975.

PaganuzzI, Bernardino: “ll segreto nelle commissioni d'inchesta", en // Parlamento della Repubblica: organi, procedure, apparati. Camera dei Deputati, vol. I, Roma 1987, págs. 377-392.

Panarello, Bedenetto Alessandro: «La structura funzionale della Commissione parlamentare per i procedimenti di accusa", en Bollettino di Informazioni Costituzionali e Parlamentari, n. ${ }^{\circ}$, 1985, págs. 137-154. 
Pierandael, Franco: «Les Commissions législatives du Parlement italien», en Revue française de science politique, II, 1952, págs. 557-580.

-: "Le commissioni legislative del Parlamento italiano", en / foro padano. Milano, IV, 1952.

PIRAs, N.: “Le commissioni parlamentari di vigilanza», en Studi parlamentari e di politica costituzionale, n. 22,1972 , págs. 41-101.

Pizzorusso, Alessandro: «La sottocommissione per la delegificazione: realtà e prospettive», en Le Regioni, n. 2-3. Bologna 1985, págs. 296-310.

RAMELLA, Pablo: "Comisiones investigadoras del Congreso", en Estudios en homenaje al doctor Héctor Fix Zamudio en sus treinta años como investigador de las ciencias jurídicas. Universidad Autónoma de México, tomo I, México 1988, págs. 639-652.

Rodriguez, M.: «Il conflitto fra commissione antimafia e magistratura (una cronaca costituzionale)", en Diritto e Società, 1976.

Rogati Valentini, E.: "Le commissioni permanenti della Camera dei Deputati», en // Politico, n. ${ }^{\circ} 3,1970$, págs. 511-537.

Rolla, G.: La Commissione per la questioni regionali nei rapporti tra Stato e Regioni. Milano 1979.

Salz Arnalz, Alejandro: «La comisión bicameral para las reformas institucionales en Italia", en Revista Vasca de Administración Pública, n. ${ }^{\circ}$, 1984, págs. $425-448$.

SALVI, Giovanni: «Verso una nuova Commissione parlamentare di inchiesta sulle stragi?», en Questione Guistizia, n. ${ }^{\circ} 3,1987$, págs. 518-527.

SAnchez Ferriz, Remedio: "La Comisión parlamentaria italiana para la dirección y la vigilancia de los servicios radiotelevisivos», en Revista de las Cortes Generales, n. ${ }^{\circ} 12,1907$, págs. 329-385.

SeCHI, Federico: "Le Commissioni bilaterali», en / Parlamento nella Costituzione e nella realtà. Atti, regolamenti e prassi della Camera nella VII Legislatura. Atti del Convegno del Gruppo Parlamentare Radicale. Roma 1978, Milano, Giuffrè, 1979, págs. 285-289.

SCHELLKNECHT, Helmut: «ll sistema delle Commissioni parlamentari», en BOIlettino di Informazioni Costituzionali e Parlamentari, n. ${ }^{\circ} 1,1985$, páginas 3-104. 
ScotrI, Italo: «La Commissione bilancio nel ciclo annuale di bilancio», en BoIlettino di Informazioni Costituzionali e Parlamentari, n. ${ }^{\circ}$, 1987, páginas $145-167$.

Silvestri, G.: «Considerazioni sui poteri e i limiti delle commissioni parlamentari di inchiesta", en $/ /$ Politico, n. ${ }^{\circ} 3,1970$, págs. 538-588.

Stramaccl, M.: "Commissioni parlamentari deliberanti", en Montecitorio, n. ${ }^{\circ} 6,1961$, págs. 35-37.

-: «l pareci delle commissioni parlamentari sugli oneri finanziari dei progetti di legge», en Montecitorio, n. ${ }^{\circ}$ 3, 1961, págs. 29-33.

TESTI, C. A.: “Ancora sui rapporti tra Autorità giudiziaria ordinaria e commissioni parlamentari di inchiesta", en La giustizia penale, I, 1977, páginas 206 y ss.

VAlentinI, Elio Rogati: «Le Commissioni Permanenti della Camera dei Deputati», en // Politico, n. ${ }^{\circ} 3,1970$.

VergottinI, Giuseppe de: «Les investigations des commissions parlementaires en Italie», en Rivista di Diritto Pubblico, 1985.

-: "Les investigations des commissions parlementaires en Italie», en Revue du Droit Public et de la Science Politique en France et à l'Etranger, 1985 (1), págs. 37-51.

VIRGA, Pietro: “Le Commissioni miste», en Rivista trimestrale di Diritto Publico, 1953, págs. 513 y ss.

ZAKRzEWSKA, I.: "Uchwalance ustaw przez komisje parlamentare Italii", en Panstwo i prawo, n. ${ }^{\circ} 8-9,1963$, págs. 255-264.

ZAMPETTI, Ugo: «Note sull'attivittà consultiva delle commissione permanenti», en I/ Parlamento della Repubblica: organi, procedure, apparati. Camera dei Deputati, vol. II, Roma 1987, págs. 103-121.

-.: Idem en Rivista trimestralle di Diritto Pubblico, n. ${ }^{\circ} 1,1986$, págs. 162-184.

\section{g) Unión Soviética}

El significado concedido a las Comisiones por la Constitución soviética de 1977 fue reconocido generalmente por la doctrina ${ }^{26}$, aludiendo a

${ }^{26}$ V. gr. Oehling Ruiz, Hermann: «La nueva Constitución soviética de 1977», en Revista de Estudios Políticos, n. 2 (NE), 1978, pág. 74. 
sus funciones de investigación, control y técnica ${ }^{27}$. Destacaba la iniciativa legislativa que el artículo 113 de la Constitución concedía a las Comisiones del Soviet Supremo de la URSS y a las Comisiones permanentes de cada una de sus Cámaras (Soviet de la Unión y Soviet de las Nacionalidades) así como el examen previo o complementario de los proyectos de ley por una o varias comisiones cuando se considere necesario (art. 114). Por último se debe resaltar el papel de la Comisión mixta paritaria de conciliación creada en el artículo 115 en caso de desacuerdo entre el Soviet de la Unión y el Soviet de las Nacionalidades. Dicha Comisión se encargaría de elaborar una propuesta de acuerdo que es examinada por las dos Cámaras en reunión conjunta. Persistiendo la discrepancia, el asunto se trasladaba a su estudio por la siguiente sesión del Soviet Supremo de la URSS o lo someteria éste a votación popular, posibilidad que la doctrina entendió en su momento remota "habida cuenta de la "homogeneidad" politica de ambas Cámaras" ${ }^{28}$.

En la actualidad, ese rol de las Comisiones parlamentarias se ha mantenido, incluso aumentado, tras la reforma operada por la Ley de revisión del texto constitucional aprobada por el Soviet Supremo de la URSS el 1 de diciembre de 1988. En su virtud, las sesiones del Soviet Supremo de la URSS se llevan a cabo por medio de reuniones separadas y conjuntas de las dos Cámaras que lo integran (Soviet de la Unión y Soviet de las Nacionalidades), asi como de las Comisiones permanentes de las mismas (art. 112) que son coordinadas por el Presidium del Soviet Supremo de la URSS (art. 119) y que siguen conservando el derecho de iniciativa legislativa (art. 114). Del mismo modo, continua la Comisión mixta paritaria de conciliación (art. 117) para el caso de divergencia entre el Soviet de la Unión y el Soviet de las Nacionalidades. Su decisión se somete a una segunda vuelta, en sesión conjunta de ambas Cámaras. Si no se llega a un acuerdo definitivo, la cuestión se envía al conocimiento del Congreso de los Diputados populares de la URSS.

Las Comisiones permanentes de las dos Cámaras del Soviet Supremo de la URSS se encargan, según el artículo 122, de redactar los proyectos de ley, del examen preliminar y la preparación de las cuestiones de competencia del Soviet Supremo. Por último es de resaltar que la lista y elección de funcionarios como integrantes del Consejo de Ministros de la URSS, del Comité de control popular de la URSS, de la Corte Suprema y de otros órganos se llevan a cabo, según el artículo 123, previo parecer de las

${ }^{27}$ Debbasch, Charles; Pontier, Jean Marie; Bourdon, Jacques; Ricci, Jean Claude: Droit Constitutionnel et Institutions Politiques, 2. ${ }^{a}$ ed., Económica, Paris 1988 , pág. 310.

28 Esteban, Jorge de, y Varela, Santiago: La Constitución soviética. Facultad de Derecho, Universidad Complutense de Madrid, Madrid 1978, pág. 103. 
correspondientes Comisiones permanentes de las Cámaras o de los Comités del Soviet Supremo de la URSS.

El papel destacado de las Comisiones se evidencia también en la obligación de todos los órganos estatales y sociales así como de los funcionarios de dar respuesta a las peticiones de las Comisiones de las Cámaras y de aportarles los materiales y documentos necesarios. Las recomendaciones de las Comisiones permanentes están sujetas al examen obligatorio por parte de los órganos estatales. El resultado de ese examen y las medidas consecuentes deben ser comunicadas a las Comisiones en el plazo establecido por ellas.

BHALERAO, S. S.: "The Supreme Soviet of the USSR and its Standing Committees", en BHALERAO, S. S., The second Chamber. Its role in modern legislatures. New Delhi, National Publishing House, 1977, págs. 90-101.

Benezera, Geneviève: «Les Commissions permanentes au Soviet Suprême de I'URSS», en Annuaire de l'URSS, 1968, págs. 145-176.

Georgadze, M. P.: Verkhovnyi sovet SSSR (1975), págs. 111-143: Postoiannye komissii.

IVASHICHENKo, O. I.: «Deiatel'nosti Ekonomitecheskoi komissii Soveta Natsional'nostei Verkhovenego Soveta SSSR i iee dal'neishee sovershenstvovanie v suete Programmy KPSS", Sovetskoe gosudarstvo i pravo, 1962, n. $^{\circ}$, págs. $39-488$.

Kravtchuk, S. S.: «Povyshenie roll postolannykh komissii palat v delatel'nosti Verkhovnogo soveta SSSR", en KRAVTCHUK, S. S.: Problemy razvitila predstavitel'nykh organov vlasti sots/alistitcheskogo gosudarstva. Moskva, Izd. Moskovskogo Universiteta, 1979, págs. 6-55.

Krutogolov, M. A.: Talks on Soviet democracy, Moscow, Progress Publishers, 1980 (págs. 123-124: Committees).

KUTAFIN, Oleg Emil'ianovitch: «Nekotorye voprosy organizatsii i deiatel'nosti postoiannykh komissii palat Verkhovnego Soveta SSSR", Vestnik Moskovskogo Universiteta, Seriia pravo, $1964, \mathrm{n} .^{\circ} 3$, págs. 31- 39.

-: «Postoiannye komissii po delam moledezhi Sovetev», Sovetskoe gosudarstvo i pravo, 1971, n. ${ }^{\circ}$, págs. 100-104.

-: Postoiannye komissii palat Verkhovnogo soveta SSSR, Moskva, luriditeheskaia literatura, 1971. 
KUTAFIN, Oleg Emil'ianovitch: «Pravovoe polozhenie postoiannych komissii palat Verkhovnogo soveta SSSR", Vestnik Moskovskogo Universiteta, Seriia pravo, 1964, n. ${ }^{\circ}$, págs. 23-33.

-: "Vzaimootnosheniia postoiannykh komissii palat Verkhovnogo soveta SSSR s Prezidiumom Verkhovnogo soveta SSSR i s Sovetom ministrov SSSR", Sovetskoe goswdarstvo i pravo, 1966, n. 4 , págs. 32-40.

-: «Nekatorie voprosy organizatsii i deiatel'nosti postoiannykh komissii palat Verkhovnogo soveta SSSR» (1964), Vestnik Moskovskogo Universiteta, n. ${ }^{\circ}$, págs. 31-39.

Maknnenko, A. Kh.: Postoiannye komissii Verkhovnogo soveta SSSR i Verkhovnykh sovetov soiuznykh Respublik, Moskva, Znanie, 1969.

-: «Povyshenie roli i sovershenstvovanie deiatel'nesti postoiannykh komissii Verkhovnykh sovetov $v$ oblasti podgotovki zakonoproektov", Sovetskoe gosudarstvo i pravo, 1964, n. $^{\circ} 8$, págs. 56-66.

-: "Razvitie i sovershenstvovanie kontrol'noi deiatel'nosti postoiannykh komissii Verkhovenykh sovetov", Sovestsnkoe gosudarstvo i pravo, 1965, n. ${ }^{\circ}$, págs. $22-28$.

Novikov, S. G.: «O dal'neishem sovershenstvovanii raboty komissii zakonodatel'nykh predpolozhenii palat Verkhovnogo soveta SSSR», Sovetskoe gosudarstvo i pravo, 1966, n. ${ }^{\circ} 10$, págs. 16-34.

-: "Utchastie nautchnoi obshtchestvennosti $v$ rabote komissii zakonodatel'nykh predpolozhenii Verkbovnogo soveta SSSR po podgotovke zakonoproektov", Sovetskoe posudarstvo $i$ pravo, 1963, n. ${ }^{\circ} 12$, páginas 56-66.

Olson, David M.: The legislative process. A comparative approach. London, Harper \& Row, 1980, págs. 299-302 (Committees).

RusiLov, D. R., \& S. G. Novikov.: "Voprosy sovershenstvo vaniia raboty komissii zakonodatel'nykh predpolozhenii Soveta Natsional'nostei», Sovetskoe gosudarstvo i pravo, 1961, n. 10.

Safronov, V. M.: «Povysheniie roli postoiannykh Komissii verkhovnykh organov vlasti», en Sovetskoe gosudarstvo $i$ pravo, 1971, n. ${ }^{\circ} 7$, páginas $123-217$.

Semin, I. S.: “Nekotorye voprosy deiatel'nosti biadzhetnoi komissii Soveta Soiuza Verkhovnogo soveta SSSR", en Sovetskoa gosudarstvo i pravo, 1962, n. ${ }^{\circ} 11$, págs. 23-37. 
Sminnov, A.: «Come funzionano le Commissioni per il bilancio del Soviet Supremo dell'URSS", Montecitorio (1964), n. $7-9$, págs. 96-101.

Ustinov, G.: "Permanent Committees of the Supreme Soviet», New Times, April 1972, págs. 18-20.

Ustinova, L. I.: Prestavitel'stvo siuznykh respublik $\vee$ postoiannykh komissiakh palat Verkhovnogo soveta Soiuza SSSR", Sbornik aspirantskikh rabot Sverdlovskogo iuriditcheskogo instituta, 1975, n. ${ }^{\circ} 18$, págs. 5-9.

VASHTCHENko, G.: «Tvortcheskii vklad deputatskikh komissii», Sovety deputatov trudiashtchikhsia, 1978, n. ${ }^{\circ}$ 2, págs. 7-14.

WIE funktionieren die Ständigen Kommissionen des Obersten Sowjets der UdSSR?. Sozialistische Theorie und Praxis, 1974, n. ${ }^{\circ} 10$, págs. 67-71.

\section{h) Otros paises}

Hasta aquí se han señalado los sistemas más característicos en la aparición y desarrollo de las Comisiones parlamentarias. Pero no son los únicos. Por ello se apuntan ahora, a modo de ejemplos y como información complementaria y en alguna manera anecdótica, estudios sobre estos órganos en países de las más diversas estructuras de poder político.

Argelia

Brève présentation de l'Assemblée popularire (1981) (págs. 3-6: Commissions).

\section{Argentina}

Bidart Campos, Germán: El derecho constitucional del poder, tomo I, Ediar, Buenos Aires 1967 (págs. 265-268: Las Comisiones). 


\section{Australia}

«House of Representatives. Introduction of Estimates Committees», en The Table, n. ${ }^{\circ} 48,1980$, págs. $146-148$.

\section{Bahamas}

“Committee structures», en The Table, n. ${ }^{\circ} 49,1981$, págs. 106-107.

\section{Bélgica}

VanWelkenhuyzen, A.: “Les Commissions permanentes du Parlement belge», en Rapports belges au Xème. Congrès International de Droit comparé. Bruxelles, Bruylant, 1978, págs. 387-417.

\section{Brasil}

MARques, G. X.: «Da importancia das comissoes no processo legislativo», en Congreso. Câmara dos Deputados. Do processo legislativo, 1972, págs. 219-244.

\section{Canadá}

Les Comités de la Chambre des Communes du Canada: guide pratique, preparé par la Direction des Comités, par le Bureau des projets de loi $d^{\prime}$ interêt public et par la Direction des Recherches pour le Bureau, $2 .{ }^{a}$ ed., Ottawa 1989.

\section{Chile}

Ahumada Muñoz, I.: Las Comisiones Parlamentarias en Chile y en otros paises. Santiago de Chile 1967. 


\section{China}

TSIEN TCHE-HAO: La République populaire de Chine. Droit constitutionnel et institutions, 1970 (págs. 230-231: Les Commissions).

Cuba

Parlamento. Asamblea Nacional del Poder Popular de Cuba, 1981 (págs. 8185: Las Comisiones).

\section{Dinamarca}

DamgaARD, E.: The function of Parliament in the Danish political system: Results of recent research, 1980 (págs. 105-106: Committees).

India

Lok Sabha Secretariat. Parliament of India, 1976 (págs. 12-14: Committees).

\section{Irlanda}

Green, Alan J.: “The Northern Ireland Assembly and Accountability of Goverment: the statutory committees, 1982-1986», en Parliamentary Affairs, Oxford 1987, págs. 90-112.

Israel

MahleR, G. S.: The Knesset. Parliament in the israeli political system, 1981 (págs. 89-90, 194-200: Committees). 


$$
\text { Japón }
$$

Baerwald, H. H.: Japan's Parliament, 1974 (págs. 134-136: The standing committees).

Libano

Sleiman, S.: Le Parlement libanais, 1978 (págs. 131-133: Commissions).

$$
\text { Noruega }
$$

Karstensen, P.: Norway's Parliament. The Storting, 1980 (págs. 8-9: Committees).

\section{Portugal}

Souza Barriga, J. A. de: A Assembleia da República, 1982 (págs. 32-37: As Comissôes).

\section{Suiza}

Santschy, A.: Le droit parlementaire en Suisse et en Allemagne, 1982 (páginas 195-236: Commissions).

\section{Uruguay}

TAYLOR, Ph. B.: Government and politics of Uruguay, 1960 (págs. 74-77: Legislative Committees and legislative processes: Committees). 
Yugoslavia

KARDEIJ, E: La nouvelle Assemblée fédérale yougoslave, 1964 (págs. 40-49: Les Comites).

\section{Zambia}

National Assembly. Members hanbock, 1980; (págs. 59-81: Committees).

\section{España}

La aparición de las Comisiones en España es temprana, anterior incluso a la primera de nuestras Constituciones. En efecto, el Reglamento Interior de las Cortes Constituyentes de 24 de noviembre de 1810 les dedicaba su Capítulo VII («De las Comisiones»), distinguiendo entre Comisiones particulares de carácter fijo y Comisiones especiales.

Aceptadas por la Constitución de Cádiz, tenían encomendado incluso el análisis previo de los proyectos de ley si lo requiriese la gravedad del asunto a juicio de las Cortes (art. 134). El rasgo de permanente referido a estas Comisiones nace, sin embargo, si bien a modo de excepción, con el Reglamento del Congreso de los Diputados de 14 de febrero de 1838 refiriéndose en su artículo 85 por primera vez a seis Comisiones que serían permanentes: Actas electorales, Presupuestos, Examen de cuentas, Peticiones, Gobierno Interior y Corrección de estilo.

La generalización de la naturaleza permanente de las Comisiones en España se produce con el Reglamento Interior de las Cortes Constituyentes de 5 de agosto de 1873, sustituido pronto en la Restauración por el viejo sistema de Secciones y Ponencias especiales hasta la reforma reglamentaria de 1918 incorporando de nuevo las Comisiones permanentes.

Esta inestabilidad es manifestación de la experiencia de nuestro parlamentarismo decimonónico, «ficticia y pobre» ${ }^{29}$, nacida de los turbios manejos de la voluntad electoral y sometido en gran parte a decisiones que se tomaban fuera del ámbito estrictamente parlamentario. Por ello al re-

29 Cuevas y Cuevas, Miguel: «Las Comisiones permanentes en los Parlamentos de Francia y España", en Revista General de Legislación y Jurisprudencia, tomo 147,1925 , pág. 389. 
ferirse a las Comisiones en nuestro país, CUEVAS señala que su origen se debe, "sin previas inquietudes, a una iniciativa del Gobierno. La implantación, pues, del sistema de Comisiones permanentes no viene al Parlamento español gracias a la preocupación que le merezca su vida propia, sino como una dádiva, entre imposiciones del Gobierno del Rey; a falta de aquella preocupación es este último el que le llama la atención sobre ese excelente instrumento de trabajo, y como una donación, le ofrece la iniciativa. Las Comisiones permanentes, no obstante su importancia y la trascendencia que podía tener el cambio, vienen a la política española con todos los caracteres de lo que nace sin esfuerzo" ${ }^{30}$. No es de extrañar por ello el desinterés en el tratamiento doctrinal sobre las comisiones en nuestra historia, similar al que puede detectarse, en general, sobre la mayoría de los temas de Derecho parlamentario. La situación no mejoró durante la II República ${ }^{31} \mathrm{y}$, por razones obvias, se acentuó en el transcurso del régimen surgido de la Guerra Civil ${ }^{32}$.

Vigente nuestra actual Constitución, las Comisiones han adquirido un nivel de importancia considerable constituyendo, para RUBIO LLORENTE, «quizá el rasgo más destacado del procedimiento legislativo español... la primacía que en él tienen las Comisiones legislativas permanentes" ${ }^{33}$. Ello no obstante, la atención de los autores sobre el particular no ha sido hasta ahora excesiva, pues si bien existían comentarios y artículos de categoría incuestionable se echaba en falta un estudio con afán exhaustivo, realidad que sólo muy recientemente se ha producido con la publicación de la monografía del profesor VILLACORTA.

Amorós Dorda, Francisco Javier: «Artículo 76. Comisiones de Investigación», en Comentarios a las Leyes Políticas. Constitución Española de 1978. Dirigidos por Óscar Alzaga Villaamil, tomo VI, EDERSA, Madrid 1989, págs. 539-593.

30 Cuevas y Cuevas, Miguel: «Las Comisiones permanentes en los Parlamentos...", op. cit., pág. 390.

${ }^{31}$ Sobre las Comisiones parlamentarias en este periodo pueden verse las referencias contenidas en HERRERo, Vicente: "Sobre el nuevo Reglamento de las Cortes" (II), en Revista de Derecho Público, n. ${ }^{\circ} 41$, 1935, págs. 129-132.

${ }_{32}$ Sobre el particular, notas generales en obras referidas a este periodo, v. gr. Fraile Clivilles, Manuel: Comentario al Reglamento de las Cortes. Instituto de Estudios Políticos, Madrid 1973, págs. 305-527; Iglesias Selgas, Carlos: Las Cortes españolas. Pasado, presente y futuro. Cabal, editor, Madrid 1973, págs. 215-230.

33 RuBIo LLORENTE, Francisco: «El procedimiento legislativo en España. El lugar de la ley entre las fuentes del Derecho", en Revista española de Derecho Constitucional, n. ${ }^{\circ} 16,1986$, pág. 92. 
Arévalo Gutiérrez, Alfonso: «Reflexiones sobre las Comisiones de investigación o encuesta en el ordenamiento constitucional español», en Revista de las Cortes Generales, n. ${ }^{\circ 11}$ 1987, págs. 159-192.

Cuevas y Cuevas, Miguel: «Las Comisiones permanentes en los Parlamentos de Francia y España", en Revista General de Legis/ación y Jurisprudencia, tomo 147,1925 , págs. 333-412.

Garcia Herrera, Miguel Ángel: «La Comisión Mixta Congreso-Senado», en Revista de Estudios Políticos, (NE) n. ${ }^{\circ}$, 1978, págs. 67-95.

JIMÉNEZ CAMPO, Javier: “Sobre el control parlamentario en Comisión”, en Política y Sociedad (Estudios en homenaje a Francisco Murillo Ferrol), vol. 1, Centro de Investigaciones Sociológicas, 1987, págs. 477-492.

Lucas Murillo de la Cueva, Pablo: "Las Comisiones de investigación de las Cortes", en Revista de la Facultad de Derecho de la Universidad Complutense, Madrid 1986, n. 10 (monog.), págs. 143-173.

Maravall, José Antonio: Los reglamentos de las Cámaras legislativas y el sistema de comisiones, Instituto de Estudios Políticos, Madrid 1947.

Paniagua Soto, Juan Luis: «El sistema de Comisiones en el Parlamento español», en Revista de la Facultad de Derecho de la Universidad Complutense, Madrid 1987, n. ${ }^{\circ} 10$ (monog.), págs. 111-142.

ReCODER DE CASSO, Emilio: "Artículo 75", en Comentarios de la Constitución, dirigidos por Fernando Garrido Falla, 2. ${ }^{\circ}$ ed., Cívitas, Madrid 1985, págs. 1152-1168.

—: «Artículo 76», en Ibidem, págs. 1169-1181.

Senen Hernandez, Mercedes: «Artículo 75. El Pleno y las Comisiones", en Comentarios a las Leyes Politicas. Constitución Española de 1976. Dirigidos por Oscar Alzaga Villaamil, tomo VI, EDERSA, Madrid 1989, págs. 515-558.

Villacorta Mancebo, Luis: Hacia el equilibrio de poderes: Comisiones legislativas y robustecimiento de las Cortes. Universidad de Valladolid, Secretariado de Publicaciones, Valladolid 1989.

Nota de la Secretaría General del Congreso de los Diputados sobre la naturaleza de la Comisión de Control de la actuación de RNE y TVE, establecida en el artículo 26 de la Ley 4/1980, sobre el Estatuto de la Radio y la Televisión, en Revista de las Cortes Generales, n. ${ }^{\circ} 2,1984$, págs. 125-131. 
Nota de la Secretaría General del Congreso de los Diputados sobre unificación de convocatoria de Comisiones, en Revista de las Cortes $\mathrm{Ge}$ nerales, $n .{ }^{\circ} 4,1985$, págs. 209-211.

Dictamen de la Secretaría General del Congreso de los Diputados a requerimiento de la Comisión de investigación sobre Incompatibilidades y Tráfico de Influencias, acerca de sus competencias, procedimiento y actuación y medios legales a su alcance, en Revista de las Cortes Generales, n. ${ }^{\circ} 14,1988$, págs. 97-180.

\section{B. DIPUTACIÓN PERMANENTE}

La Diputación Permanente de Cortes es el prototipo de sistema español de continuidad parlamentaria ${ }^{34}$. Frente a' la reunión automática de la Cámara que reasume la representación nacional para el caso concreto de concurrencia de situaciones marcadas por el carácter de la excepcionalidad ${ }^{35}$ o frente a la subsistencia o renacimiento de los poderes de aquellas Cámaras que han decaído en el ejercicio regular de su representatividad, es decir, la prorrogatio ${ }^{36}$, la Diputación permanente supone la creación de un órgano ad hoc extraído del propio Parlamento con la misión específica de conservar la representación de la voluntad popular cuando aquél se encuentra en receso.

Esta figura nació en las Cortes medievales catalanas de donde se extendió a otros reinos hispánicos adquiriendo una importancia que ha llevado a considerarla «la más importante que ha creado la España medieval» ${ }^{37}$. Por ello los ejemplos de la institución en los reinos de Aragón, Cataluña, Valencia, Navarra y Castilla han sido objeto de estudio detallado.

34 Por ello Sánchez Agesta habla de «institución castiza» (SÁNCHEz AGESTA, Luis: Constitución española comentada, Centro de Estudios Constitucionales, Madrid 1979, pág. 191).

${ }_{35}$ V. gr. artículo 79 de la Constitución belga de 1831 en el caso de fallecimiento del Rey, o artículo 16 de la Constitución francesa de 1858 al establecer la reunión automática del Parlamento al producirse lo que Hauriou denomina "el ejercicio de una dictadura temporal en período de urgencia» por el Presidente de la República (Hauriou, André: Derecho Constitucional e Instituciones Politicas. Ariel, Barcelona 1971, pág. 549).

${ }_{36}$ Véase, v. gr., Romano, Antonio Augusto: La prorogatio negli organi costituzionali. Milano, Dott. A. Giuffrè, 1967.

37 Rubio । Cambronero, I.: La Diputació de Cataluña en los siglos XV y XVI. Diputación Provincial de Barcelona, Barcelona MCML, pág. 17. 
No puede decirse lo mismo respecto a su incidencia en el parlamentarismo liberal. No obstante la existencia de notables estudios cabe apuntar que el tratamiento doctrinal histórico es similar a la mayoría de los temas de Derecho parlamentario. Las obras clásicas en esta materia suelen resultar engañosas porque su título no corresponde a veces con el contenido ${ }^{38}$ siendo en ocasiones poco más que una relación de anécdotas históricas o de la vida política con escasa o nula relación con el Parlamento. Sucede también que en esos tratados generales, el análisis de la Diputación permanente adolece de tal grado de abstracción que se limita casi a dar noticia de su existencia ${ }^{39}$.

La breve experiencia republicana de 1931 supuso el relanzamiento de este órgano sin que su escasa duración diera posibilidad a la doctrina más que a elaborar reflexiones parciales dentro de los comentarios generales sobre la Constitución de 1931 o a apuntar la importancia puntual de alguna de sus decisiones. Con el régimen de Franco se crea una llamada Comisión permanente de Cortes que participaba de notas propias de una verdadera Diputación Permanente junto a rasgos extraños que desnaturalizaban su entendimiento.

En la Constitución de 1978 se vuelve a incorporar la Diputación permanente en su sentido propio con funciones efectivas, aunque limitadas, en el juego de las relaciones entre los poderes del Estado, motivo por el que la doctrina, de forma significativa estos últimos años, empieza a dispensarle la atención que merece su cometido.

En el plano del Derecho comparado, el ejemplo gaditano de 1812 se recogió en la Constitución lusa de 1822, en la napolitana de 1821 y en una pluralidad de textos hispanoamericanos, aunque eso no implica que su reconocimiento constitucional en estos últimos países fuese automático en todos ellos ni tan siquiera que en los que finalmente se aceptó, lo fuera sin poner serios reparos en cuanto futura repercusión en la eficacia y estabilidad constitucional. Así, en el caso peruano el diputado CÁRDENAS manifestó que de aceptarse este órgano «seria el borrón de la Carta del 60 , su semilla deletérea» ${ }^{40}$, mientras que alguno de sus comentaristas la ca-

38 V. gr. Fernandez Martín, Manuel: Derecho Parlamentario Español, 3 tomos, Imprenta de los Hijos de J. A. García, Madrid 1885; LuQUE y VICENS, D. A.: Las Cortes Españolas. Establecimiento Literario-Tipográfico Saavedra y Compañia, Madrid 1850.

39 V. gr. Pons y UMBERT, Adolfo: Organización y funcionamiento de las Cortes según las Constituciones españolas y Reglamentos de dicho Cuerpo Colegislador. Hijos de G. Hernández, Madrid 1906, págs. 58-64, se limita a resumir los debates constitucionales sobre la Diputación permanente en 1812.

40 Cfr. Pareja Paz-Soldán, José: Las Constituciones del Perú. Ediciones de Cultura Hispánica, Madrid 1954, págs. 244-245. 
lificaban sin más de «institución absurda» ${ }^{41}$. Un segundo período de aparición de órganos de este tipo se produce después de la Primera Guerra Mundial, siendo numerosas las Constituciones (entre ellas la alemana de 1919 y la checoslovaca de 1920) que recogen lo que PÉREZ SERRANO denominaba "comisiones ultrapermanentes" ${ }^{42}$. Por último, aparece en los textos más recientes y progresistas de la Europa occidental (portuguesa de 1976, griega de 1975) siendo aceptada de buen grado por la doctrina ${ }^{43}$ aunque sin dedicarle una atención preferente que se plasme en estudios específicos.

Antecedentes medievales

Arvizu y Galarraga, F.: “Sanción y publicación de leyes en el Reino de Navarra», en Anuario de Historia de Derecho Español, 32, Madrid 1972, págs. 733-744.

Beneyto Perez, Juan: Historia de la Administración española e hispanoamericana. Aguilar, Madrid 1958.

—: Instituciones de Derecho histórico español. Bosch, Barcelona 1931.

Capmany, Antonio de: Práctica y estilo de celebrar Cortes en el Reino de Aragón. Imprenta de don José de Collado, Madrid 1821.

Castellano, Juan Luis, Las Cortes de Castilla y su Diputación (1621-1789). Entre pactismo y absolutismo, Centro de Estudios Constitucionales, Madrid 1990.

FONT Rıus, José Maria: Instituciones medievales españolas. Consejo Superior de Investigaciones Científicas, Madrid 1949.

Garcia de Valdeavellano, Luis: Curso de Historia de las Instituciones Españolas. De los origenes al final de la Edad Media. Quinta edición, Revista de Occidente, Madrid 1977.

41 Pareja Paz-Soldán, José: Las Constituciones del Perú, op. cit., pág. 245.

42 Pérez Serrano, Nicolás, op. cit., pág. 763.

43 Así, para Soares Martínez la figura "parece justificada" dentro del texto portugués (MARTínez SoARes: Comentarios à Constituçao portuguesa de 1976. Editorial Verbo, Lisboa 1978, pág. 221). 
Gonzalez Antón, Luis: Las Cortes de Aragón. Librería General, Zaragoza 1977.

Hinojosa, Eduardo de: Estudios sobre la Historia del Derecho Español. Imprenta del Asilo de Huérfanos del Sagrado Corazón de Jesús, Madrid 1903.

Huicı Goñı, María del Puy: Las Cortes de Navarra durante la Edad Moderna. Universidad de Navarra. Institución Príncipe de Viana, Ediciones Rialp, Madrid 1963.

IDOARTE, Florencio: «La primera Diputación de Navarra», en Anuario de Historia del Derecho Español, 40, 1970, págs. 539-549.

LALINDE Abadia, Jesús: Iniciación histórica al Derecho español, 3. ${ }^{a}$ ed. Ariel, Barcelona 1983.

LUQUE y Vicens, A.: Las Cortes Españolas. Establecimiento Literario-Tipográfico Saavedra y Compañia, Madrid 1850.

Marichalar, Amalio; ManRique, Cayetano: Historia de la legislación y recitaciones del Derecho Civil en España. Imprenta Nacional, Madrid 1863.

MARQUEZ, Juan: El Gobernador christiano, Madrid MDCCLXXIII.

Martínez Aloy, José: La Casa de la Diputación de Valencia. Tip. Doménech, Valencia 1909-1910.

-: La Diputación de la Generalidad de Valencia. Diputación Provincial de Valencia, Talleres Tipográficos del Hijo de F. Vives Mora, Valencia 1930.

Martinez Marina, Francisco: Teoria de las Cortes, tomo 2, Madrid 1820. Edición preparada por José Manuel Pérez Prendes, Editora Nacional, Madrid 1979.

Moneva y Pujol, Juan: Introducción al derecho hispánico, Labor, Barcelona (s.a.).

PIskorski, Wladimiro: Las Cortes de Castilla en el periodo de tránsito de la Edad Media a la Moderna, 1188-1520. Ediciones El Albir, Barcelona 1977.

Rio Aldaz, Ramón del: Las últimas Cortes del Reino de Navarra (1828-1829). Haramburu Editor, S.A., San Sebastián 1985. 
Romeu y Alfaro, Silvia: «Notas sobre la Diputación valenciana y su extinción con Felipe V», en Actas del III Symposium de Historia de la Administración, Madrid 1974, págs. 547-584.

Rubio Cambronero, I.: La Deputació del General de Catalunya en los siglo XV y XVI, 2 vols, Diputació Provincial de Barcelona, Barcelona 1950.

SaAvedra Fajardo, Diego de: Empresas políticas o ideas de un príncipe christiano. Madrid MDCCLXXXIX.

Salcedo IzU, Joaquín: La Diputación del Reino de Navarra (1). Ediciones Universidad de Navarra, Instituto «Príncipe de Viana». Pamplona 1969.

-: Atribuciones de la Diputación del Reino de Navarra, Diputación Foral de Navarra. Instituto Príncipe de Viana, Consejo Superior de Investigaciones Científicas, Pamplona 1974.

-: «La Diputación del Reino de Navarra», en Actas del I Symposium de Historia de la Administración (1967). Escuela Nacional de Administración Pủblica, Alcalá de Henares 1970, págs. 209-214.

Salord Comellas, S.: «La Casa de la Diputación de la Generalidad de Aragón», en EEMCA, VI, Zaragoza 1951, págs. 447-450.

Sánchez Albornoz, Claudio: «Notas para el estudio del petitum», en Instituciones medievales españolas. EDIMEX, México 1965, págs 483-519.

Sempere, Juan: Histoire des Cortes d'Espagne. Bordeaux 1815.

-: Resumen de la Historia de las antiguas Cortes de España. Calero, Madrid 1834.

Sesma Muñoz, José Antonio: La Diputación del Reino de Aragón en la época de Fernando II. Libreria General, Barcelona 1977.

TomÁs y VALIENTE, Francisco: «La Diputación de las Cortes de Castilla (15251600)", en Anuario de Historia del Derecho español, 32, 1962, páginas $347-469$.

—: Manual de Historia del Derecho español, 4. ${ }^{\circ}$ ed. Tecnos, Madrid 1983.

Torre y del Cerro, Antonio de la: Origenes de la Diputación del General de Cataluña. Barcelona 1923. 


\section{Régimen constitucional histórico}

Alonso de Antonio, Ángel Luis: «La Diputación permanente en la Constitución de Cádiz», en Revista de las Cortes Generales, n. ${ }^{\circ} 13,1988$ págs. $137-$ 156.

-: La Diputación permanente de las Cortes en la historia constitucional española, Publicaciones del Congreso de los Diputados, Madrid 1991.

Fraile Clivilles, Manuel: La Comisión Permanente de las Cortes. Editora Nacional. Madrid 1974.

Gómez Rivas, José Vicente: «La Comisión de Permanencia en las Cortes Generales de 1869-1871", en Revista de las Cortes Generales, n. ${ }^{\circ} 19,1990$, págs. 217-320.

Pérez Serrano, Nicolás: “La Diputación permanente de Cortes en nuestro Derecho Constitucional Histórico" (AHDE 1932), en Escritos de Derecho Político I. Colección «Administración y ciudadano», Instituto de Estudios de Administración Local, Madrid 1984, págs. 169-192.

\section{Sistema parlamentario actual}

Alonso de ANTONIO, José Antonio: "La Diputación permanente en el sistema parlamentario español", en Revista de las Cortes Generales, n. ${ }^{\circ} 8$, 1986, págs. 139-154.

Alós Martin, Ignacio: “La Diputación Permanente en la Constitución española», en Revista de las Cortes Generales, n. ${ }^{\circ} 18,1989$, págs. 7-65.

Astarloa Huarte-Mendicoa, Ignacio: «Artículo 86. Decretos-Leyes», en Comentarios a las Leyes Politicas. Constitución española de 1978. Dirigidos por Oscar Alzaga Villaamil, tomo VII, EDERSA, Madrid 1985, págs. 139-207.

Berdugo Gómez de la Torre, Ignacio: “Los estados de alarma, excepción y sitio. Comentarios a la Ley Orgánica 4/1981, de 1 de junio», en Revista de Política Comparada. UIMP, n. ${ }^{\circ}$ 5, 1981, págs. 99-124.

Bermejo Vera, J.: "La función resolutoria de los conflictos constitucionales negativos por parte del Tribunal Constitucional», en El Tribunal Constitucional, vol. 1, Instituto de Estudios Fiscales, Madrid 1981, pág. 596. 
Carro Martinez, Antonio: "Artículo 116. Situaciones de anormalidad constitucional", en Comentarios a las Leyes Políticas. Constitución española de 1978. Dirigidos por Óscar Alzaga Villaamil, tomo IX, EDERSA, Madrid 1987, págs. 231-296.

GonzÁlez Ayala, M. ${ }^{a}$ Dolores: «La continuidad de las Cámaras Parlamentarias: Las distintas soluciones constitucionales», en Anuario de la Facultad de Derecho. Universidad de Extremadura, Cáceres 1987, n. ${ }^{\circ} 5$, págs. 73-86.

JiMÉnez CAMPo, Javier: «Las Diputaciones Permanentes y el control sobre los Decretos-Leyes», en Revista Derecho Político. UNED, n. ${ }^{\circ} 15,1982$, págs. 35-55.

Lavilla Rubira, Juan José: “Artículo 78. La Diputación permanente en el ordenamiento español", en Comentarios a las Leyes Politicas. Constitución española de 1978. Dirigidos por Óscar Alzaga Villaamil, tomo VI, EDERSA, Madrid 1989, págs. 618-721.

LuCAS MuRILlo de LA Cueva, Pablo: “Los órganos constitucionales», en Introducción al sistema politico español. Andrés de Blas y otros, Editorial Teide, Barcelona 1983, págs. 107-251.

Mellado Prado, Pilar: «El problema de la continuidad del Parlamento: la Diputación permanente», en Revista de Derecho Político. UNED, n. ${ }^{\circ} 27-$ 28,1988 , págs. $45-75$.

Monfeal Ferrer, Antoni: «Notas sobre las Diputaciones permanentes del Congreso y del Senado en la Constitución española de 1978", en la ob. col. Parlamento y Sociedad Civil. Miguel Angel Aparicio (coord.), Universidad de Barcelona, Barcelona 1980, págs. 153-164.

Paniagua Soto, Juan Luis: "Congreso de los Diputados", en Diccionario del Sistema Politico Español. Dirigido por José Juan González Encinar, Ediciones AKAL, Madrid 1984, págs. 92-99.

-: «Senado», en ibidem, págs. 821-827.

Pérez Dobón, Juan José: «Les activités parlementaires après la dissolution de la Chambre: la "Diputation permanente" espagnole", en Informations Constitutionnelles et Parlementaires, $1 .^{a}$ série, n. ${ }^{\circ} 137$, primer trimestre, Genève 1984, págs. 26-34.

Recoder de CASso, Emilio: “Artículo 78», en Comentarios a la Constitución, dirigidos por Fernando Garrido Falla, 2. ${ }^{a}$ ed., Cívitas, Madrid 1985, págs. 1189-1197. 
Santaolalla López, Fernando: «Artículo 73. Períodos de sesiones», en Comentarios a las Leyes Politicas. Constitución española de 1978. Dirigidos por Óscar Alzaga Villaamil, tomo VI, EDERSA, Madrid 1989, págs. 453-466.

Serrano Alberca, José Manuel: “Artículo 116.5", en Comentarios a la Constitución. Dirigidos por Fernando Garrido Falla, 2. ${ }^{a}$ ed., Cívitas, Madrid 1985, págs 1600-1604.

Serrera Contreras, Pedro Luis: «¿Leyes de la Diputación permanente de las Cortes?», en Revista Española de Derecho Administrativo, n. ${ }^{\circ} 24,1980$, págs. 91-96. 